\title{
A new early Pliocene locality Tepe Alagöz (Turkey) reveals a distinctive tooth phenotype of Trischizolagus (Lagomorpha, Leporidae) in Asia Minor
}

\author{
Stanislav Čermák, Peter Joniak, and Bora Rojay
}

\begin{abstract}
Pliocene leporid remains are very rare in Anatolia, occurring sporadically only in a few localities. The new locality of Tepe Alagöz (Çankırı Basin) is the first reported Pliocene locality in Turkey with sufficiently rich leporid material for determination of morphometric variability in taxonomically important teeth. The locality also yielded remains of the rodents Occitanomys debruijni, Allocricetus cf. ehiki, Pseudomeriones hansi, and an ochotonid lagomorph. The assemblage suggests an early Pliocene age (MN14) of about the same age or somewhat older than that in Iğdeli (Sivas Basin). The medium-sized leporid is characterized by p3 of almost exclusively a "Nekrolagus" pattern with narrow anteroconid and very variable anteroflexid. It is associated with P2 bearing short paraflexus, long hypoflexus, and moderately developed mesoflexus, and 11 which is anteroposteriorly shortened with a shallow, V-shaped, cement-free anterior notch. The leporid was co-identified with Trischizolagus gambariani described from the coeval locality Nurnus (Armenia). A lectotype designation and emended diagnosis of the species are provided in this paper. The available fossil record of Trischizolagus indicates that the northwestern part of the peri-Paratethyan area was inhabited by $T$. dumitrescuae, but to the south and southeast by distinct T. gambariani. The only other proven finding of Trischizolagus from Anatolia was reported from Tozaklar (MN15), but due to the scarcity of fossil material a definite species determination is impossible.
\end{abstract}

Stanislav Čermák. The Czech Academy of Sciences, Institute of Geology, Rozvojová 269, 16500 Prague 6, Czech Republic. cermaks@gli.cas.cz Peter Joniak. Comenius University, Department of Geology and Paleontology, Mlynská dolina G, Ilkovičova 6, 84215 Bratislava, Slovakia. peter.joniak@uniba.sk

Bora Rojay. Middle East Technical University, Department of Geological Engineering, 06531 Ankara, Turkey. brojay@metu.edu.tr

http://zoobank.org/3799FF43-1688-4EC4-B1DD-B8243A388A31

Čermák, Stanislav, Joniak, Peter, and Rojay, Bora. 2019. A new early Pliocene locality Tepe Alagöz (Turkey) reveals a distinctive tooth phenotype of Trischizolagus (Lagomorpha, Leporidae) in Asia Minor. Palaeontologia Electronica 22.1.14A 1-21. https://doi.org/ $10.26879 / 924$

palaeo-electronica.org/content/2019/2465-trischizolagus-of-tepe-alagoez

Copyright: March 2019 Society of Vertebrate Paleontology.

This is an open access article distributed under the terms of the Creative Commons Attribution License, which permits unrestricted use, distribution, and reproduction in any medium, provided the original author and source are credited.

creativecommons.org/licenses/by/4.0/creativecommons.org/licenses/by-nc-sa/4.0 
Key words: Tepe Alagöz; Turkey; Pliocene; Rodentia; Lagomorpha; Trischizolagus gambariani

\section{INTRODUCTION}

Despite the fact that Pliocene terrestrial deposits occupy large areas in Turkey and fossil mammals of that age are reported from many localities-comprising MN14: Akçaköy, Aşaği Page, Babadat, Çeştepe, Elbistan, Hacisam, İğdeli, Kizilpinar, Yerlikuyu; MN15: Çalta, Ericek, Mahmutlar, Ortalica, Sürsürü, Taşova, Tekman, Tozaklar, Zirnak; MN16: Gülyazi, Kadiözü, Yenice (Ünay and de Bruijn, 1998; Şen et al., 1998, 2017, 2019; Ünay et al., 2003; Suata-Alpaslan, 2009a, 2009b, 2009c, 2010, 2012; De Bruijn et al., 2013; van den Hoek Ostende et al., 2015) — there are, in the vast majority of cases, scarce and fragmentary rodent associations. Moreover, compositions of available faunal assemblages are somewhat different from those of the surrounding regions (Şen et al., 2017). Thus, unsurprisingly, the Pliocene mammal faunas of Turkey are still poorly understood.

Fossil lagomorphs have been recorded in Anatolia in more than 60 localities aged between the early Miocene and middle Pleistocene (Şen et al., 2017, 2019). However, in contrast to the relatively well-recorded representatives of the family Ochotonidae, documented with six genera in about 50 localities, the record of Leporidae is very poor in only about 10 localities (Şen et al., 2017, 2019). The Pliocene leporids are limited only to Trischizolagus reported by Ünay and de Bruijn (1998) from Tozaklar (MN15) and Pliopentalagus reported by Suata-Alpaslan $(2010,2012)$ from Babadat (MN14), Akçaköy (MN14), and Tekman (MN15). The latter genus is referred to only in faunal lists without any descriptions.

The discovery of a new Pliocene locality in Turkey with a rich leporid record gives the opportunity to increase the knowledge and understanding of Pliocene leporid history in Asia Minor. In this framework, the aim of this paper is to: 1) describe the geological setting of Tepe Alagöz and its adjacent area (Çankırı Basin), 2) provide a stratigraphic correlation of fossil mammalian assemblage from Tepe Alagöz, 3) provide a detailed morphometric analysis of the leporid material under study, 4) redescribe and emend the diagnosis of Trischizolagus gambariani (Melik-Adamyan, 1986), and 5) hypothesize a possible evolutionary and dispersal history of the early leporids in Asia Minor.

\section{GEOLOGICAL SETTING}

Tepe Alagöz is located in the SE part of the Çankırı Basin (Figure 1), one of the key Neogene
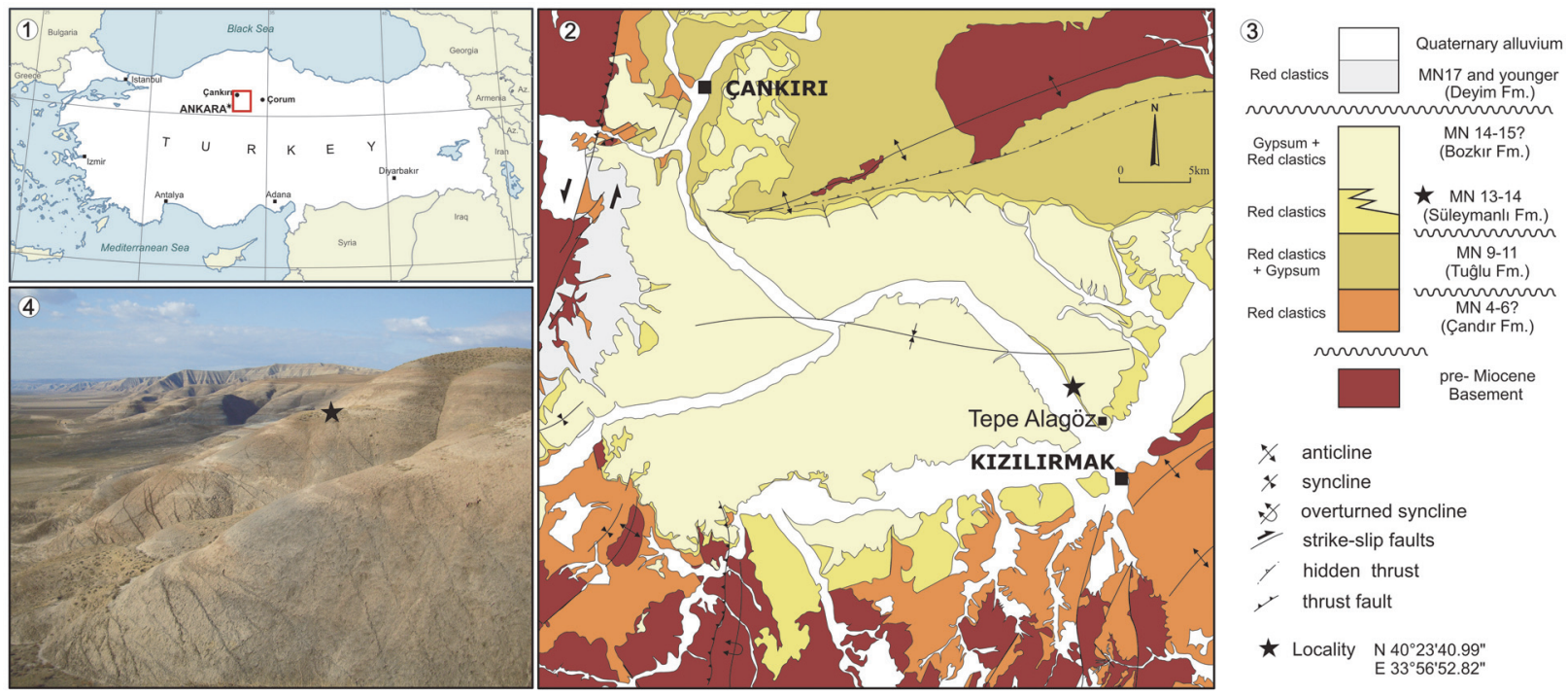

FIGURE 1. Location and geological context of Tepe Alagöz (indicated by star). 1-3, Location (1), simplified geological map (2), tentative stratigraphic section and map legend (3) of the Çankırı Basin (modified from Çiner et al., 2012); 4, Northwestern view of the locality. 
basins in Central Anatolia to the south of Pontides. The basin is situated on the ophiolitic mélanges and nappes of the Izmir-Ankara-Erzincan suture belt and bounded by the North Anatolian Fault Zone from north and Kırşehir Crystalline Complex from south.

The tectono-sedimentary evolution of the Çankırı Basin had mainly been controlled by the progressive closure of the northern Neotethys Ocean from the Late Cretaceous until the end of Miocene. During the Late Cretaceous-Paleogene, accretionary prisms and fore-arc basins were developed and followed by the Eocene age piggyback to peripheral basins (Şengör and Yılmaz, 1981; Görür et al., 1998). Following the closure of the northern Neotethys during the Miocene, the region was characterized by an evolution of intracontinental, closed, and restricted fluvial-lacustrine basins on top of Oligocene sequences and Cretaceous ophiolitic imbricated nappes (e.g., Çankırı Basin; MN1-2 to MN14-15; Çiner et al., 2012; Mazzini et al., 2013; Şen et al., 2019) accompanied with extensive Neogene volcanism (e.g., Galatian volcanic province; 22 to $10 \mathrm{Ma}$ ) in northern Central Anatolia. After the collision of Eurasian plate with southern continental fragments - African and Arabian plates - during post-middle Eocene to late
Miocene, the marine deposition in the Pontides ceased and retreated towards north (Paratethys), and to the southeast towards SE Anatolia to Basra (Iraq) (Şengör and Yılmaz, 1981).

The Çankırı Basin is developed on folded and southward-thrusted thick pre-Miocene sequences. The Oligocene gypsum-clastic sequence is overlain unconformably by early Miocene to early Pliocene sequences (Kaymakçı 2000) (Figure 2).

The Miocene Çankırı Basin can be differentiated into two parts: the western (Kalecik-Hancılı area) and the main central (Çankırı area). The early Miocene lacustrine basins on the western margin of the Çankırı Basin, under the effect of northward converging Kırşehir Block (Kaymakçı, 2000), continue as the middle to late Miocene fluvial to shallow lacustrine deposits in the rest of the Çankırı Basin (Lüttig and Steffens, 1976). During the latest Miocene-Pliocene, the Anatolian Plateau was fully covered by fluvial red clastics.

Deposition to the west was in two cycles: 1) the first was fluvio-lacustrine with swampy conditions where the mudrocks with limnic beds - even coal beds - developed in the earliest Miocene and 2) the second one was fluvio-lacustrine where red clastics and green-to-beige mudrocks with limnic beds developed during the early Miocene (Çiner et

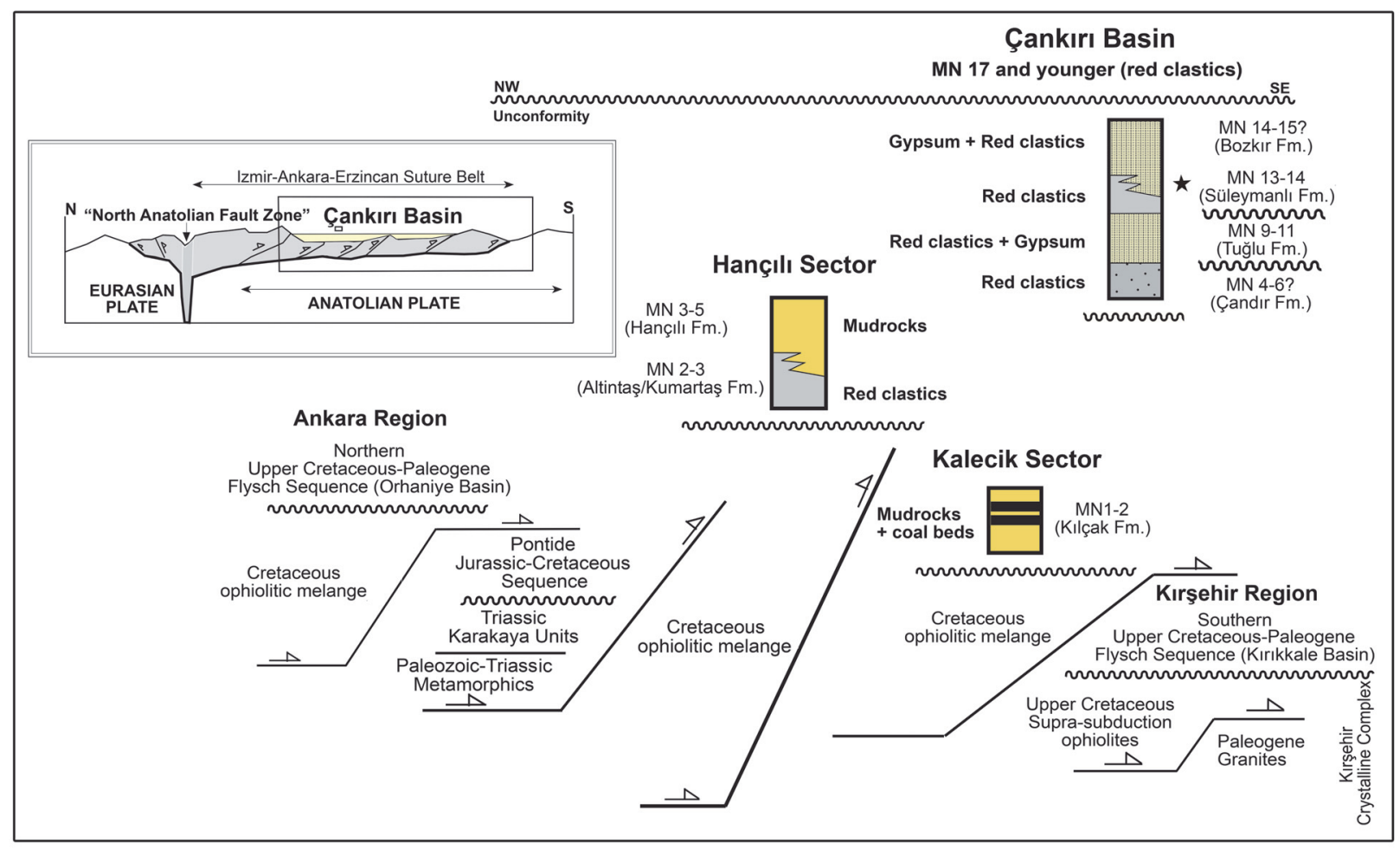

FIGURE 2. Tentative cross section depicting the tectono-stratigraphy of the Çankırı Basin (modified from Kaymakçı, 2000; Rojay et al., 2004; Mazzini et al., 2013). 
al., 2012) (Figure 2). The early Miocene mudrocks dominant along the western margin of the Çankırı Basin are missing in the rest of the basin. The early Miocene series in western Çankırı Basin are intensively folded and deformed compared to the uppermost early-middle Miocene ones in the rest of the basin. There is a possible tectonic saddle (elevated Cretaceous ophiolitic units) where an almost N-S sinistral strike-slip fault follows the saddle between the western parts and rest of the basin.

In the central part of the basin, the infilling sediments were deposited in two different sedimentary cycles during the Miocene: 1) the first were fluvio-lacustrine red clastics to green-to-beige mudrocks of the Burdigalian-early Serravalian (MN4-6?) fluvial red clastic deposition, in some places followed unconformably or gradually by Tortonian (MN9-11) mudrock-clastic sequences with limnic layers (Mazzini et al., 2013) and 2) the second one is made up of continental red clastics alternating upward with evaporites of middle to late Miocene age and the red beds of early Pliocene (Figure 2). The target lithology is a relatively undeformed sequence of sandstone to siltstone at Tepe Alagöz section, which are overlain by gypsum beds in the center of Çankırı Basin (Figures 1, 2). Sampling was done along the southern limb of a broad syncline.

Briefly, the Miocene evolved completely within a fluvial to lacustrine depositional setting during the early Miocene (MN1-2) to early Pliocene (MN14) in an extensional basin. This basin evolved on top of an imbricated accretionary ophiolitic belt with a short gap during the late Serravalian (MN7-8 period). The steeply dipping to overturned Miocene deposits are overlain unconformably by the late Pliocene (MN17) fluvial red beds along the basin margins.

In summary, within the Miocene cycle, seven different depositional periods have been distinguished linked to progressive and intermittent indentation of the Kırşehir Block. These are (Figure 2): MN1-2 (Kılçak Formation) and MN2-3 (Altıntaş/ Kumartaş Formation) in western margin of the Çankırı Basin; MN3-5 (Hançılı Formation); MN4-?6 (Çandır Formation); MN 9-11 (Tuğlu Formation); MN13-?14 (Süleymanlı Formation); and MN14-?15 (Bozkır Formation) in the rest of the basin.

\section{MATERIAL AND METHODS}

The described material was recovered from $\sim 250 \mathrm{~kg}$ of sandy silt excavated in the locality Tepe Alagöz during summer of 2008. The sediment was processed following a conventional screen-wash- ing procedure using a set of stable sieves with the small mesh size of $0.5 \mathrm{~mm}$. The fossil remains were picked manually in the laboratory of Comenius University. The described material is stored in the Natural History Museum of the EGE University in Izmir (Turkey). The full format of specimen numbers is EUNMH PV30500, but in the following text we only use the format PV30500. Casts of the rodent teeth are stored in the collections of Department of Geology and Paleontology, Comenius University in Bratislava (Slovakia). Measurements were made using a calibrated micrometer eyepiece on the Leica MZ75 stereomicroscope. All dimensions are given in millimeters [mm]. Rodent teeth were photographed using an analytical SEM microscope Hitachi VP-SEM S-3700N, and lagomorph teeth were drawn using a camera lucida mounted on the stereomicroscope. Terminology used for teeth parts follows van de Weerd (1976) for Murinae; Daams and Freudenthal (1988), Cuenca-Bescós (2003) for Cricetinae; Tong (1989) for Gerbillinae; Şen (1998) for Ochotoninae; and Palacios and López Martínez (1980) and Čermák et al. (2015) for Leporinae. Morphotype classification used to describe teeth P2/p3 in Leporidae follows Fladerer (1987), Fladerer and Reiner (1996), Čermák (2009), and Čermák et al. (2015). The interspecific comparisons were made with the material held in the Department of Geology and Paleontology, Comenius University in Bratislava, Czech National Museum in Prague, Institute of Geology of the Czech Academy of Sciences in Prague, and/or on a bibliographical basis. Unless otherwise stated, data were taken from the original descriptions of species. Biostratigraphic terminology follows de Bruijn et al. (2013). All nomenclatural acts presented here conform to the mandatory provisions of the International Code of Zoological Nomenclature (ICZN, 1999).

Abbreviations. A0-A1 = general enamel p3 patterns of Leporidae defined by the combination of presence/absence of anteroflexid (sensu Čermák et al., 2015); $\mathbf{B M R}=$ buccal mesial reentrant (mesoflexus) of P2 in Leporidae; c1 = accessory posterior cuspid in $\mathrm{m} 1$ of Muridae; $\mathbf{l} / \mathbf{i}=$ upper/lower incisors; $L$ = length; $L L=$ lingual lobe of P2 in Leporidae; $\mathbf{M} / \mathbf{m}=$ upper/lower molars; $\mathbf{M B R}=$ major buccal re-entrant angle (hypoflexid) of p3 in Leporidae; $\boldsymbol{m a x}=$ maximum; $\boldsymbol{m i n}=$ minimum; $\mathbf{N}=$ number of specimens; OR = observed range; $\mathbf{P} / \mathbf{p}=$ upper/lower premolars; Pa0-Pa3, PR0-PR4 = general enamel p3 patterns of Leporidae defined by the degree of development of paraflexid [Pa], and morphostructures between the trigonid and talonid 


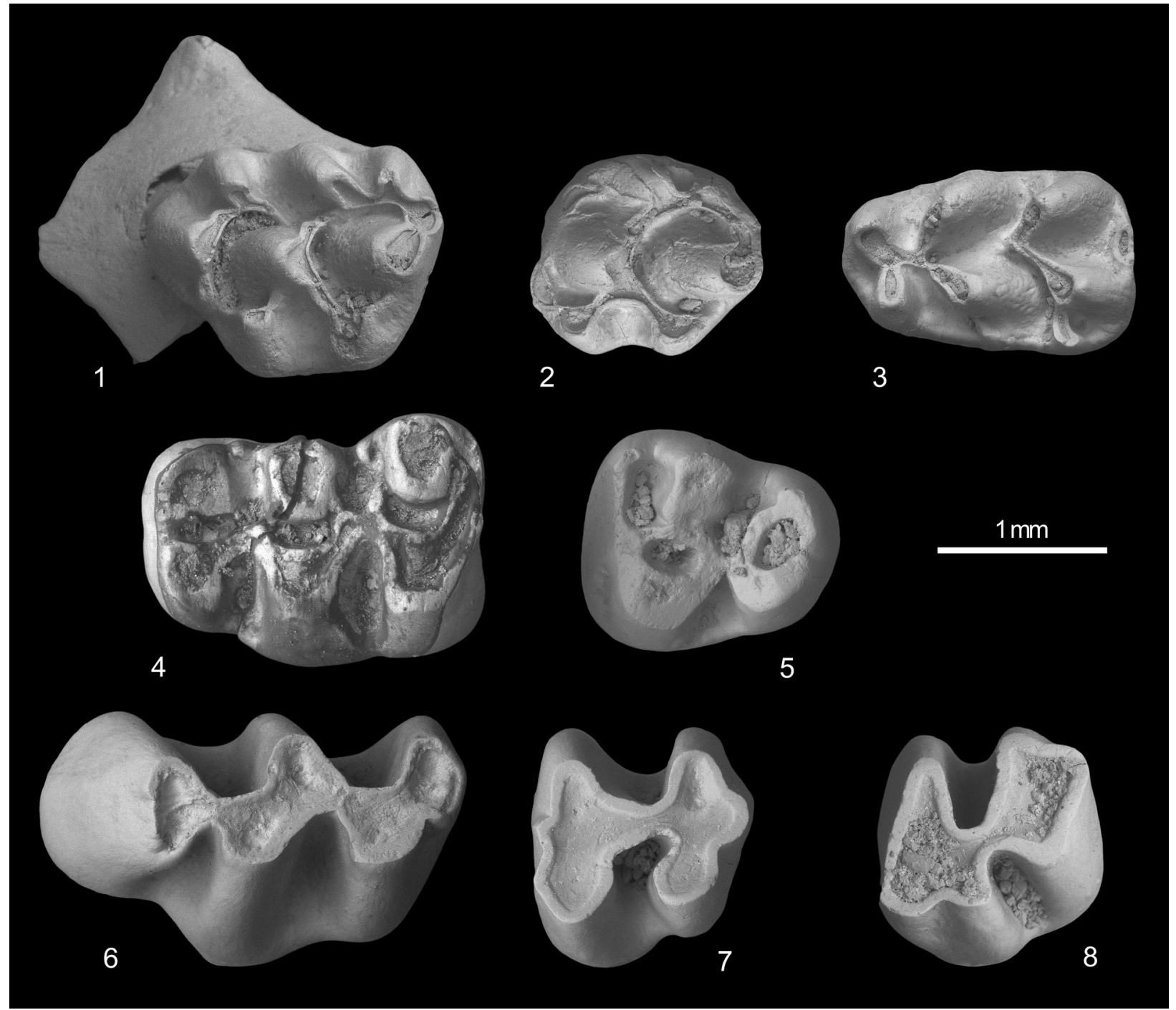

FIGURE 3. Rodent teeth from Tepe Alagöz. 1-3, Occitanomys debruijni: 1, right M1 (PV30500), reversed; 2, right M2 (PV30501), reversed; 3, right $\mathrm{m} 1$ (PV30502), reversed. 4-5, Allocricetus cf. ehiki: 4, left M1 (PV30504); 5, left M3 (PV30505). 6-8, Pseudomeriones hansi: 6, left M1 (PV30506); 7, left M2 (PV30507); 8, right m2 (PV30508), reversed.

[PR] (sensu Čermák et al., 2015); t1-t12, t1 bis, and $\mathbf{t} \mathbf{2}$ bis = upper molar cusps of Murinae (sensu van de Weerd,1976); $\mathbf{W}=$ width; $\overline{\mathbf{x}}=$ arithmetic mean.

\section{SYSTEMATIC PALEONTOLOGY}

Class MAMMALIA Linnaeus, 1758 Order RODENTIA Bowdich, 1821

Family MURIDAE Illiger, 1811

Subfamily MURINAE Illiger, 1811

Genus Occitanomys Michaux, 1969

Occitanomys debruijni (Şen et al.,1989)

Figure 3.1-3

Material and measurements. $1 \mathrm{M} 1$ dex, PV30500 $(\mathrm{LxW}=1.90 \times 1.42) ; 1 \mathrm{M} 2$ dex, PV30501 (LxW = 1.42x1.24); 2 m1 dex, PV30502 (LxW = 1.75x1.14), PV30503 (LxW = -x1.02).

\section{Description}

M1. (Figure 3.1) The tooth has oval occlusal outline. The $\mathrm{t} 1$ is connected to the $t 5$, while low connection to the $\mathrm{t} 2$ is through well-developed $\mathrm{t} 1$ bis. The $t 2$ bis is weak. The $t 3$ connects to the base of the $t 5$ by posterior spur. There is a continuous circle connection between t4-t5-t6-t9-t12t-t8. The $\mathrm{t} 7$ is absent, and $\mathrm{t} 12$ is developed as a posteriorly placed, rounded cusp between the t8 and t9. The tooth has three roots.

M2. (Figure 3.2) The $\mathrm{t} 1$ is large and connected to the $t 5$ and to the $t 1$ bis. The $t 3$ is small and tearshaped. The high, circular connection between t4- 
t5-t6-t9-t8 is well developed. The t4 is connected to the base of the t8, and the t 12 is absent. The tooth has three roots; two labial and one lingual that is wide and formed by intergrowth of two roots.

m1. (Figure 3.3) One of the two specimens is damaged in its anterior part. In the complete one the anterocentral cusp is absent, and the anteroconid cusps are connected to the protoconid-metaconid. The longitudinal spur is present in one specimen, while absent in the second one. The oval posterior tuberculum is well developed in both specimens. The $\mathrm{c} 1$ is developed as an elongated cusp connected to the base of hypoconid. Accessory labial cusp is on cingulum or as separate cusp. Both teeth have two roots.

Comparison and remarks. The teeth of Occitanomys debruijni from Tepe Alagöz are comparable in their size with those of the type material from Maritsa. They also fit in the upper size range of the type material of $O$. vandami described by SuataAlpaslan (2009b) from İgdeli, but the M1 under study is slightly wider. However, de Bruijn et al. (2013, figure 26.2) mentioned from İğdeli only one species, $O$. debruijni. The differences between $O$. vandami and $O$. debruijni are subtle and we agree that $O$. vandami probably represents a synonym of $O$. debruijni. The material available from Tepe Alagöz is too scanty for statistical evaluation of morphological characters, but it shares discriminative features of $O$. debruini from its type locality of Maritsa (de Bruijn et al., 1970) and Develi (Şen et al., 1989). The material under study is also similar to that of O. debruijni from Tomea Eksi 2 (Hordijk and de Bruijn, 2009), but differs in having more developed posterior spur on $\mathrm{t} 3$, as in the type material from Maritsa (de Bruijn et al., 1970; Hordijk and de Bruijn, 2009). In contrast, M2 from Tepe Alagöz has only three roots while those from Tomea Eksi have four. Hordijk and de Bruijn (2009) stated that none of the M2 available from the type locality shows even an incipiently split lingual root, and this character is probably variable within the Occitanomys group.

Subfamily CRICETINAE Fischer, 1817 Genus Allocricetus Schaub, 1930 Allocricetus cf. ehiki Schaub, 1930 Figure 3.4-5

Material. $1 \mathrm{M} 1$ sin, PV30504 (LxW = 2.12x1.48); 1 M3 sin, PV30505 (LxW = 1.56x1.34).

\section{Description}

M1. (Figure 3.4) The anterocone is wide and splits into two equal cusps separated by the narrow central valley. The forked anterolophule connects to both anterocone cusps. The lingual branch of the anterolophule is stronger than the labial one. The protoloph is double; the posterior protolophule is better developed than the anterior one. The lingual sinuses are slightly deeper than labial ones. The parastyle is weaker than the mesostyle. The medium-long mesoloph connects to the metacone. The strong posteroloph is long, forming a posterolabial border of the tooth and connects to the metacone. Only the anterior root is preserved but the traces of three other roots are visible.

M3. (Figure 3.5) The labial anteroloph is strong and long, enclosing anterosinus, while lingual anteroloph is strongly reduced. The double protoloph forms a funnel between the protocone and paracone. The mesoloph is absent. The reduced metacone is fused in the ridge that encloses the posterior funnel. The tooth has three roots.

Comparison and remarks. The very limited material shows the morphological features typical for Allocricetus such as the 1) wide anterocone that is deeply split from behind, 2) double protolophule, and 3) absence of the metalophule and wellformed funnels between the main cusps. The overall morphology, size, and the presence of the parastyle and mesostyle support an attribution of the available material in $A$. ehiki. However, the material is very scanty, and since we do not have any lower molar, the above teeth are tentatively assigned here as Allocricetus cf. ehiki Schaub, 1930.

Subfamily GERBILLINAE Gray, 1825

Genus Pseudomeriones Schaub, 1934

Pseudomeriones hansi Suata-Alpaslan, 2009a

Figure 3.6-8

Material. $1 \mathrm{M} 1 \mathrm{sin}, \mathrm{PV} 30506(\mathrm{LxW}=2.57 \times 1.58) ; 1$ M2 sin, PV30507 (LxW = 1.38x1.48); $1 \mathrm{~m} 2$ dex, PV30508 (LxW = 1.58x1.51).

\section{Description}

M1. (Figure 3.6) The tooth crown is high and its occlusal surface is rather narrow. The anterocone is placed slightly labially while the main cusps are clearly alternating. The anteroloph is in a line with the neoloph. The protosinus and sinus are equally developed and deeper than the mesosinus. The posterior sinus (sulcus) is small but clearly separates the posteroloph from hypocone. The roots are not preserved.

M2. (Figure 3.7) The occlusal surface is slightly concave. The protocone is more massive than other cusps. The anteroloph is small but distinctive while the posteroloph is developed as a wide oblique structure. The mesosinus is wide while the sinus is narrower and strongly curved backward. 
Both sinus and mesosinus are equally deep. Two roots are preserved; the anterior one shows a tendency for bifurcation.

m2. (Figure 3.8) The tooth has two main lobes separated by anteriorly directed sinusid and mesosinusid. The mesosinusid is longer and slightly deeper than sinusid. A shallow protosinusid is developed on the labial side of anterior lobe. A weak posterosinusid is outlined on the posterolingual side of the posterior lobe. The tooth has two roots.

Comparison and remarks. The tooth morphology of Pseudomeriones from Tepe Alagöz is almost identical to this of $P$. hansi from İğdeli described by Suata-Alpaslan (2009a). Slight differences, such as the 1) more pronounced posterior sinus (sulcus) in $M 1,2$ ) more developed anteroloph, and 3) unsplit anterior root in $\mathrm{M} 2$, seem to be ontogenetic because young and unworn specimens are predominantly represented in the assemblage under study. Sizes of available teeth from Tepe Alagöz are within the upper size range or slightly larger than those of $P$. hansi. Comparably large teeth of $P$. latidens and $P$. tchaltaensis differ morphologically.

Order LAGOMORPHA Brandt, 1855

Family OCHOTONIDAE Thomas, 1897

Subfamily OCHOTONINAE Thomas, 1897

Ochotona seu Ochotonoma sp.

Figure 4.1-2'

Material and measurements. P2 sin, PV30668 $(\mathrm{LxW}=0.67 \times 1.52) ; \mathrm{P} 2$ sin, $\mathrm{PV} 30669(\mathrm{LxW}=$ 0.8x1.43); 2 fragments of I1, PV30670-PV30671.

\section{Description}

P2. Single-lobed tooth of variable occlusal outline with well-developed long paraflexus; hypercone sharpened, anteriorly with enamel hiatus; lagicone with undulated anterior enamel wall; in the former specimen (Figure 4.1) the posterior enamel wall of tooth and the anterior enamel wall of hypercone are both convex, in contrast to the latter one (Figure 4.2) with concave posterior enamel wall of tooth and hypercone with secondary protrusion.

Comparison and remarks. The availability of only two P2s from Tepe Alagöz makes a direct comparison with many taxa impossible. Moreover, this scarce material, without any p3s and/or mandibles, does not allow a definite specific/generic attribution. The first ochotonine occurrence in Asia Minor is dated to $9.9 \mathrm{Ma}$ at Sinap Loc. 8A with Bellatonoides eroli (Şen, 2003). Compared to the material under study, P2 of $B$. eroli is of similar size, but morphologically seems to be different (based only on two P2s available; cf. Şen, 2003) in less-devel- oped paraflexus and hypercone, without enamel hiatus. The oldest representatives of the genus Ochotona in the peri-Paratethyan area are 0 . ozansoyi Şen, 2003 from Sinap Loc. 84, Turkey and O. kalfense Lungu, 1981 from Kalfa, Moldova (Čermák, 2016); both dated to the late Vallesian (early MN10) [Şen, 2003; Čermák, 2016]. Both species differ from the Tepe Alagöz ochotonid in their larger size of $\mathrm{P} 2$, which have a nearly trapezoidal outline with a short paraflexus. Ochotona eximia (Khomenko, 1914) described from the late Miocene (middle Turolian, MN12) locality of Tarakliya (Moldova) is one of the largest species of the genus (Čermák, 2016). Estimated indirectly from p3 size $(\mathrm{LxW}=2.2 \times 2.0)$, it should be significantly larger than the taxon from Tepe Alagöz (Čermák, 2016). This is also true for all three species of the genus Pliolagomys Agadjanian and Erbajeva, 1983 (see Erbajeva, 1988; Erbajeva and Shushpanov, 1988; Čermák, 2010 for details). In size, the analyzed P2s are comparable with 1) Ochotona antiqua Argyropulo and Pidoplichka, 1939, well documented from the early Ruscinian (MN14) localities of Ukraine and Moldova (Erbajeva and Shushpanov, 1988; Čermák and Rekovets 2010) and 2) the slightly younger genus Ochotonoma Şen, 1998, well documented from the late Ruscinian (MN15) localities of Turkey, Bulgaria, Romania, and Hungary (Terzea, 1997; Ünay and de Bruijn, 1998; Şen, 1998, et al. 2019; Popov, 2004; Čermák, 2007). Ochotonoma also has very similar P2 morphology; in a number of P2 specimens, their lagicone is anteriorly undulated, and the hypercone possesses a secondary protrusion (see Terzea, 1997; Ünay and de Bruijn, 1998; Şen, 1998). Ochotona mediterranensis described by SuataAlpaslan (2009c) from the contemporaneous (MN14) locality İğdeli has P2 slightly smaller ( $\bar{x}$ : $\mathrm{LxW}=0.64 \times 1.18 ; \mathrm{N}=7$ ), but unfortunately its morphology remains unclear. This species was also referred by Şen et al. (2017) from the early Ruscinian (MN14) locality of Çeştepe, sharing close similarities in size and tooth morphology with the Iğdeli specimens. Ochotona sp. ( $O$. mediterranensis sensu Suata-Alpaslan, 2009c and Şen et al., 2017) from Maritsa, Greece (MN13/14) seems to be, indirectly estimated based on $\mathrm{p} 3$ dimensions, smaller than ochotonine taxon from Tepe Alagöz, (cf. de Bruijn et al., 1970; Čermák, 2016). Unfortunately, no P2 is available from Çeştepe and Maritsa.

The only available P2 are most compatible with those in the above discussed Pliocene species of Ochotona and Ochotonoma. Unfortunately, the analyzed teeth do not bear sufficient diagnostic 

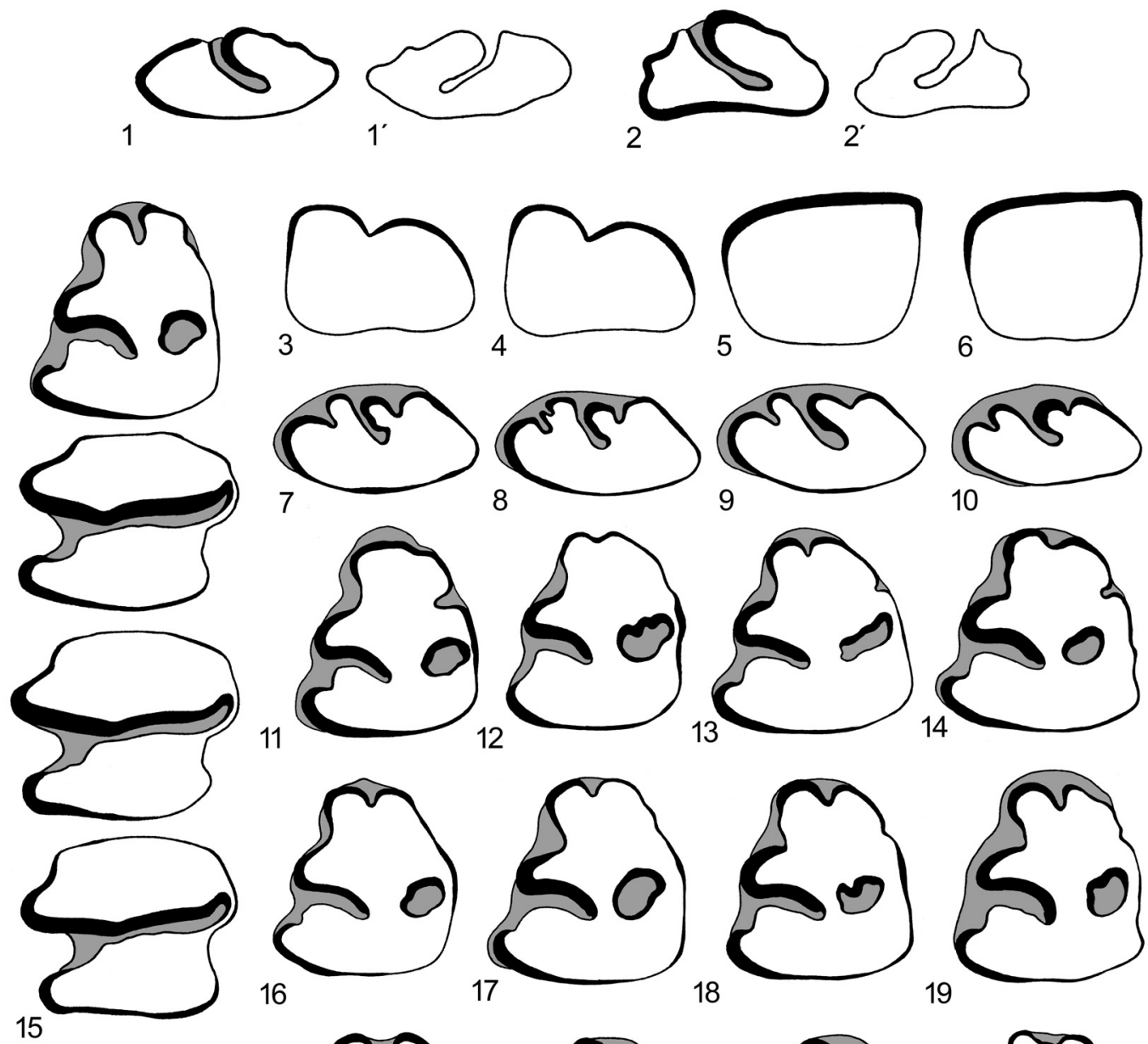

8

9

10
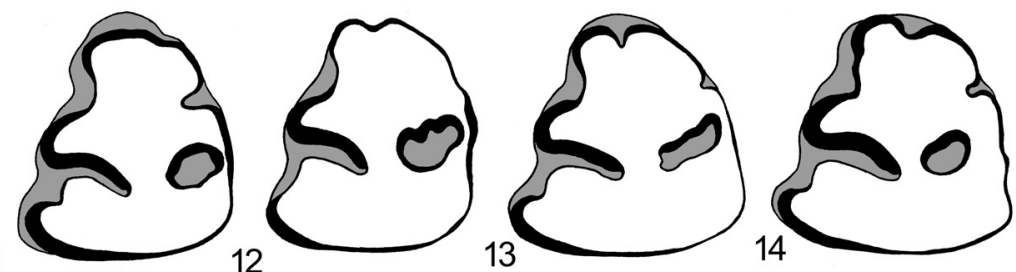

16
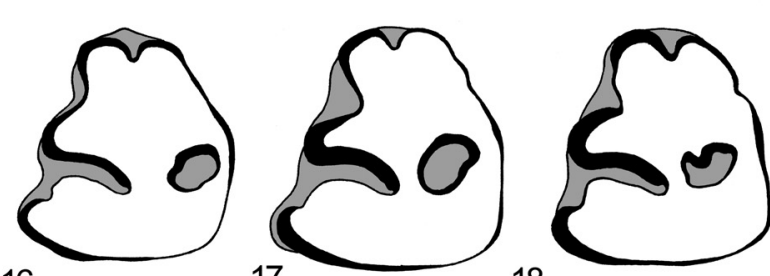

18

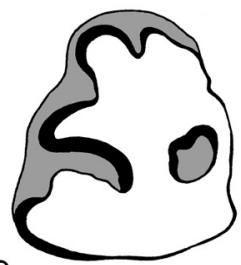

19
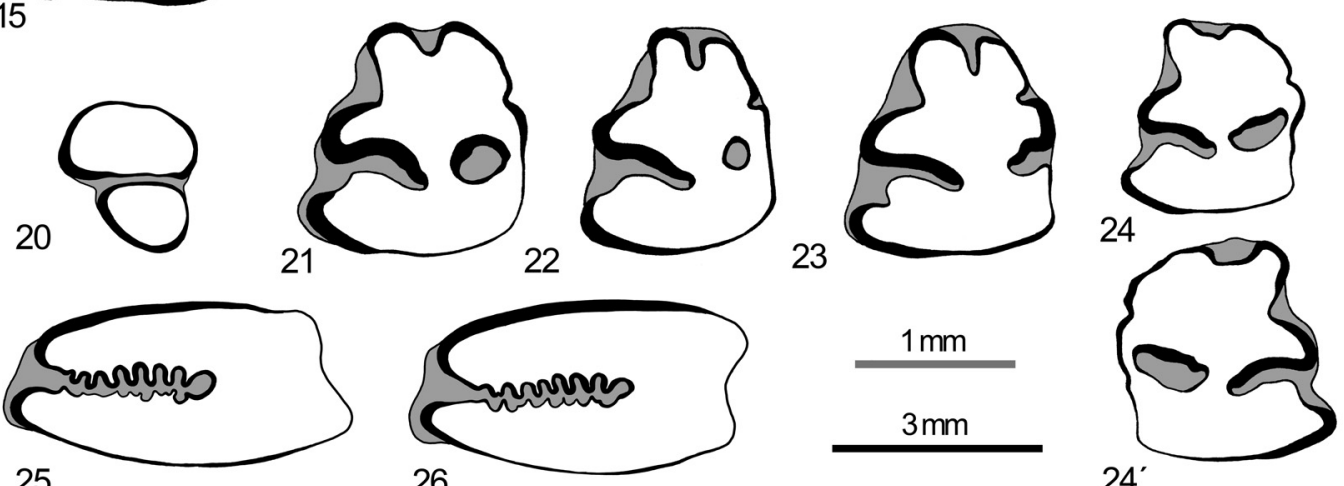

25

26

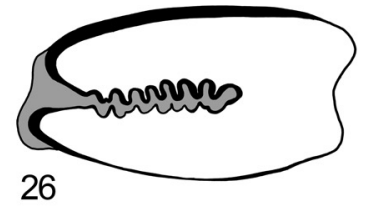

$24^{\prime}$

FIGURE 4. Lagomorph teeth from Tepe Alagöz. 1-2', Ochotonidae: 1-1', left P2 (PV30668), occlusal and root views; 2-2' left P2 (PV30669), occlusal and root views. 3-26, Leporidae: 3, right I (PV30530), cross-section, reversed; 4, left I (PV30531), cross-section; 5, right i (PV30532), cross-section, reversed; 6, right i (PV30534), cross-section, reversed; 7, left P2 (PV30523), occlusal view; 8, right P2 (PV30524), occlusal view, reversed; 9, right P2 (PV30525), occlusal view, reversed; 10, left P2 (PV30526), occlusal view; 11, left p3 (PV30527), occlusal view; 12, left p3 (PV30511), occlusal view; 13, left p3 (PV30512), occlusal view; 14, right p3 (PV30520), occlusal view, reversed; 15, right p3-m2 (PV30528), occlusal views, reversed; 16, right p3 (PV30516), occlusal view, reversed; 17, right p3 (PV30518), occlusal view, reversed; 18, left p3 (PV30510), occlusal view; 19, left p3 (PV30513), occlusal view; 20, left m3 (PV30629), occlusal view; 21, right p3 (PV30517), occlusal view, reversed; 22, left p3 (PV30509), occlusal view; 23, left p3 (PV30521), occlusal view; 24-24', left juvenile p3 (PV30515), occlusal and root views; 25, right P3 (PV30661), occlusal view, reversed; 26, right P3 or M1 (PV30611), occlusal view, reversed. Scale bars: grey (1 mm) for Ochotonidae, black (3 $\mathrm{mm}$ ) for Leporidae. 
TABLE 1. Dental measurements of Trischizolagus gambariani from Tepe Alagöz (Turkey). CV = coefficient of variation [\%], $\mathrm{I} / \mathrm{i}=$ upper and lower incisors, $\mathrm{L}=$ length, $\mathrm{M} / \mathrm{m}=$ upper and lower molars, $\mathrm{N}=$ number of specimens, OR = observed range, $\mathrm{P} / \mathrm{p}=$ upper and lower premolars, $\mathrm{W}=$ width, Want $=$ anteroloph width in upper molariforms, $\mathrm{Wi}=$ width of isthmus between anteroloph and posteroloph in upper molariforms, Wpost = posteroloph width in upper molariforms, Wtrig = trigonid width in lower molariforms, Wtal $=$ talonid width in lower molariforms, $\bar{x}=$ arithmetic mean .

\begin{tabular}{|c|c|c|c|c|c|c|c|c|c|c|c|}
\hline \multicolumn{6}{|c|}{ Lower teeth } & \multicolumn{6}{|c|}{ Upper teeth } \\
\hline & & $\mathbf{N}$ & $\overline{\mathbf{x}}$ & OR & CV & & & $\mathbf{N}$ & $\overline{\mathbf{x}}$ & OR & CV \\
\hline \multirow[t]{2}{*}{ i1 } & L & 16 & 2.43 & $2.29-2.52$ & 2.72 & 11 & L & 2 & - & $2.17 ; 2.20$ & - \\
\hline & W & 16 & 3.16 & $2.91-3.41$ & 4.81 & & W & 2 & - & $3.07 ; 3.11$ & - \\
\hline \multirow[t]{2}{*}{ p3 } & L & 15 & 3.36 & $3.16-3.56$ & 3.69 & P2 & L & 4 & 1.77 & $1.68-1.82$ & 3.67 \\
\hline & W & 15 & 3.11 & $2.96-3.36$ & 3.67 & & W & 4 & 3.38 & $3.12-3.48$ & 5.06 \\
\hline \multirow[t]{3}{*}{ p4 } & L & 11 & 2.93 & 2.83-3.09 & 2.49 & P3 & L & 6 & 2.30 & $2.00-2.45$ & 7.13 \\
\hline & Wtrig & 11 & 3.32 & $3.14-3.45$ & 2.83 & & Want & 6 & 3.63 & $3.08-3.95$ & 9.39 \\
\hline & Wtal & 11 & 2.77 & $2.55-3.00$ & 4.87 & & Wpost & 6 & 4.41 & $3.75-4.80$ & 9.23 \\
\hline \multirow[t]{3}{*}{ m1 } & L & 8 & 2.96 & $2.87-3.03$ & 2.16 & & Wi & 6 & 1.22 & $1.10-1.48$ & 11.97 \\
\hline & Wtrig & 8 & 3.36 & $3.13-3.55$ & 3.93 & P4/M1 & L & 7 & 2.40 & $2.28-2.55$ & 4.13 \\
\hline & Wtal & 8 & 2.73 & $2.53-3.00$ & 5.42 & & Want & 7 & 4.26 & $4.10-4.70$ & 4.74 \\
\hline \multirow[t]{3}{*}{ m2 } & L & 10 & 2.99 & $2.86-3.08$ & 2.31 & & Wpost & 7 & 4.18 & $3.85-4.70$ & 7.22 \\
\hline & Wtrig & 10 & 3.22 & $3.00-3.38$ & 3.60 & & Wi & 7 & 1.21 & $1.08-1.35$ & 9.17 \\
\hline & Wtal & 10 & 2.67 & $2.45-2.90$ & 4.49 & M2 & L & 4 & 2.15 & $2.05-2.25$ & 3.81 \\
\hline \multirow[t]{3}{*}{ m3 } & $L$ & 11 & 2.19 & $2.05-2.30$ & 4.02 & & Want & 4 & 3.85 & $3.80-3.95$ & 1.84 \\
\hline & Wtrig & 11 & 1.98 & $1.80-2.15$ & 4.80 & & Wpost & 4 & 3.30 & $3.18-3.40$ & 3.21 \\
\hline & Wtal & 11 & 1.27 & $1.15-1.55$ & 8.82 & & Wi & 4 & 1.10 & $1.05-1.23$ & 7.64 \\
\hline
\end{tabular}

features and, therefore, it is impossible to determine the genus or species. Without further relevant ochotonid material from Tepe Alagöz they are tentatively assigned here as Ochotona seu Ochotonoma sp.

Family LEPORIDAE Fischer, 1817

Subfamily LEPORINAE Fischer, 1817

Genus Trischizolagus Radulesco and Samson, 1967

Trischizolagus gambariani (Melik-Adamyan, 1986) Figure 4.3-26, Table 1

Nomeclatural remarks and lectotype designation. The species-group name gambariani was originally erected by Melik-Adamyan (1986) in the tentative, but unambiguous, combination with the generic name Alilepus (cf. Article 11.9.3.4 of ICZN, 1999). The species description fulfills the mandatory conditions of Article 13.1.1 (ICZN, 1999). The nominal species-group taxon was established based on the syntype (Article 73.2 of ICZN, 1999) consisting of 10 specimens with four p3s (MelikAdamyan, 1986: 136, 137; figures 1-3). No single name-bearing type specimen was subsequently designated (lectotype [Article 74]).

In the sense of Articles 74.7 and 74.4 and Declaration 44 , we hereby designate the left p3 fig- ured (Article 74.4) in Melik-Adamyan (1986, p. 137, figure 3; Article 74.7.2) as a lectotype (Article 74.7.1 and Declaration 44) of the nominal taxon of Trischizolagus gambariani (Melik-Adamyan, 1986) described from the early Pliocene (MN14) locality Nurnus (Armenia).

Name-bearing type, type locality, and age. Lectotype (designated in this paper) - left p3 figured in Melik-Adamyan (1986, p. 137, figure 3); Nurnus (Armenia), early Pliocene (early Ruscinian, MN14). Material. 1 I1 dex, PV30530; 1 I1 sin, PV30531; 4 fragments of 11, PV30542, PV30453, PV30560, PV30666; 3 12, PV30637-PV30639; 2 P2 dex, PV30524, PV30525; 2 P2 sin, PV30523, PV30526; 1 fragment of P2, PV30541; 4 P3 dex, PV30617, PV30660-PV30662; 2 P3 sin, PV30618, PV30659; 5 P4/M1 dex, PV30608-PV30612; 2 P4/M1 sin, PV30606, PV30607; 2 M2 dex, PV30615, PV30616; 2 M2 sin, PV30613, PV30614; 4 fragmentary or juvenile M3, PV30640-PV30642, PV30667; 8 fragments of upper molariforms, PV30619-PV30626; 1 fragment of mandibular body dex with p3-m2, PV30528; 9 i1 dex, PV30532, PV30533, PV30534, PV30545, PV30546, PV30551, PV30655-PV30657; 7 i1 sin, PV30547-PV30550, PV30649, PV30653, PV30654; 7 fragments of i1, PV30552, PV30554- 
PV30557, PV30664, PV30665; 2 i1 juv, PV30553, PV30663; 7 p3 dex, PV30516-PV30520, PV30522, PV30529; 9 p3 sin, PV30509-PV30515, PV30521, PV30527; 8 fragments of p3, PV30535-PV30539, PV30544, PV30558, PV30559; 4 p4 dex, PV30565-PV30568; 6 p4 sin, PV30561-PV30564, PV30650, PV30658; 2 m1 dex, PV30573, PV30574; 5 m1 sin, PV30569-PV30572, PV30651; $3 \mathrm{~m} 2$ dex, PV30580-PV30582; 6 m2 sin, PV30575PV30579, PV30652; 8 m3 dex, PV30630PV30636, PV30648; 3 m3 sin, PV30627-PV30629; 5 fragmentary or juvenile m3, PV30643-PV30647;1 milk lower tooth, PV30605; 22 fragments of lower molariforms, PV30583-PV30604.

Measurements. See Table 1.

\section{Description}

i1. (Figure 4.5-6) Quadrangular, markedly prolonged anteroposteriorly; anterior enamel wall thick with constant thickness.

p3. (Figure 4.11-14, 15 [partim], 16-19, 24-24') Almost exclusively limited to PR2 pattern (presence of mesofossettid) associated with $A 1$ pattern (presence of anteroflexid), in one case (Figure 4.11) PR2 pattern is associated with $A 0$ pattern (absence of anteroflexid) and in one case (Figure 4.23) PR1 pattern (presence of mesoflexid) is associated with $\mathrm{A} 1-(\mathrm{A} 1 / \mathrm{PR} 2=88 \%, \mathrm{~A} 0 / \mathrm{PR} 2=$ $6 \%, A 1 / P R 1=6 \%, N=16)$; all teeth with stable pattern along the entire tooth crown, including one juvenile tooth (Figure 4.24-24'); depth of anteroflexid very variable from $0 \%$ (missing) to $18 \%$ (long) of $L$ (average $=12 \% ; N=16$ ); the anteroconid narrow, its length ranges from $25 \%$ to $33 \%$ of $L$ (average $=30 \% ; N=16$ ), size relationship between labial and lingual anteroconids is variable; protoflexid quite wide with variable angle between enamel walls, its depth varies from $13 \%$ to $20 \%$ of $\mathrm{W}$ (average $=17 \% ; \mathrm{N}=15$ ); a shallow paraflexid or concavity is present in $87 \%(\mathrm{~N}=15)$ of specimens, and in six cases the notch is filled with cement; mesofossettid variable in its size and morphology; hypoconid massive, its labial side, predominantly deformed anterolabially by a depression (morphotype "c" [sensu Čermák, 2009]; 76\%, N = 17); hypoflexid not crenulated, reaching about half

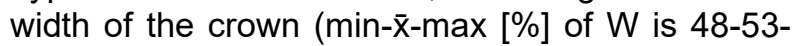
$59 \%$ ), its lingual end simple - predominantly of morphotype "A" (sensu Fladerer and Reiner, 1996; $41 \%, N=17$ ) and morphotype "B" (sensu Fladerer and Reiner, 1996; 35\%, $N=17$ ).

Lower molariforms. (Figure 4.15 [partim]) Trigonid - in relation to talonid - small with smooth anterobuccal corner (no flexid present); labial part of the talonid anterolabially concave; isthmus between trigonid and talonid thin and long; flexid between trigonid and talonid smooth; very thick enamel on the labial part of the tooth and on the trigonid posterior edge.

m3. (Figure 4.20) Typically bean-shaped trigonid, larger and wider than the oval talonid, the both with thicker enamel on labial sides.

I1. (Figure 4.3-4) Occlusal outline of irregular quadrangle, anteriorly prolonged in its medial part; anterior enamel thin with no substantial variation; anterior notch shallow, V-shaped with widely opened walls, not filled with cement; anterior notch divides the tooth in two parts of approximately equal anterior prominence, the medial one $(\sim 46 \%$ of $W$ ).

P2. (Figure 4.7-10) Occlusal outline oval; paraflexus short, its length on average $56 \%(\mathrm{~N}=4)$ of tooth length; hypercone advanced, with relatively long hypoflexus of LL-morphotype between $\mathrm{V}$ and VI (sensu Fladerer and Reiner, 1996); lagicone with moderately developed mesoflexus of BMRmorphotype B (sensu Fladerer and Reiner, 1996).

Upper molariforms. (Figure 4.25-26) Hypostria quite short, markedly crenulated, with abundant cement lingually; typically thicker enamel on the anterior part of the anteroloph and the lingual tips of posteroloph; relatively thin enamel in the anterior part of the anteroloph.

Comparison and remarks. The leporid from Tepe Alagöz is attributed here to the genus Trischizolagus Radulesco and Samson, 1967 for showing the following combination of discriminant features: 1) the presence of anterofelxid in p3 (= A1 morphotype; in $94 \%, N=17$ ), 2) the presence of short hypoflexid associated with mesofossettid (= PR2 morphotype; in $94 \%, \mathrm{~N}=16$ ), and 3) the exclusive presence of simple - uncrenulated - flexids in lower teeth. This discriminates the leporid under study from Old World: 1) species of Hypolagus Dice, 1917 which bear A0/PR0 p3; 2) species of Serengetilagus Dietrich, 1941 with A0-1/PR0 p3; 3) species of Alilepus Dice, 1931 bearing A0/PR1-2 p3; 4) species of Pliopentalagus Gureev and Konkova in Gureev, 1964 which have crenulated flexids in lower teeth; and 5) species of Lepus Linnaeus, 1758 and Oryctolagus Lilljeborg, 1874 bearing A1/PR3 $\mathrm{p} 3$.

In p3 morphology the leporid from Tepe Alagöz is fully compatible with the stratigraphically and geographically close species $T$. gambariani described from the contemporaneous (MN14) locality of Nurnus (Armenia). In addition to the significant presence of a PR2 p3 pattern (Figure 5), 


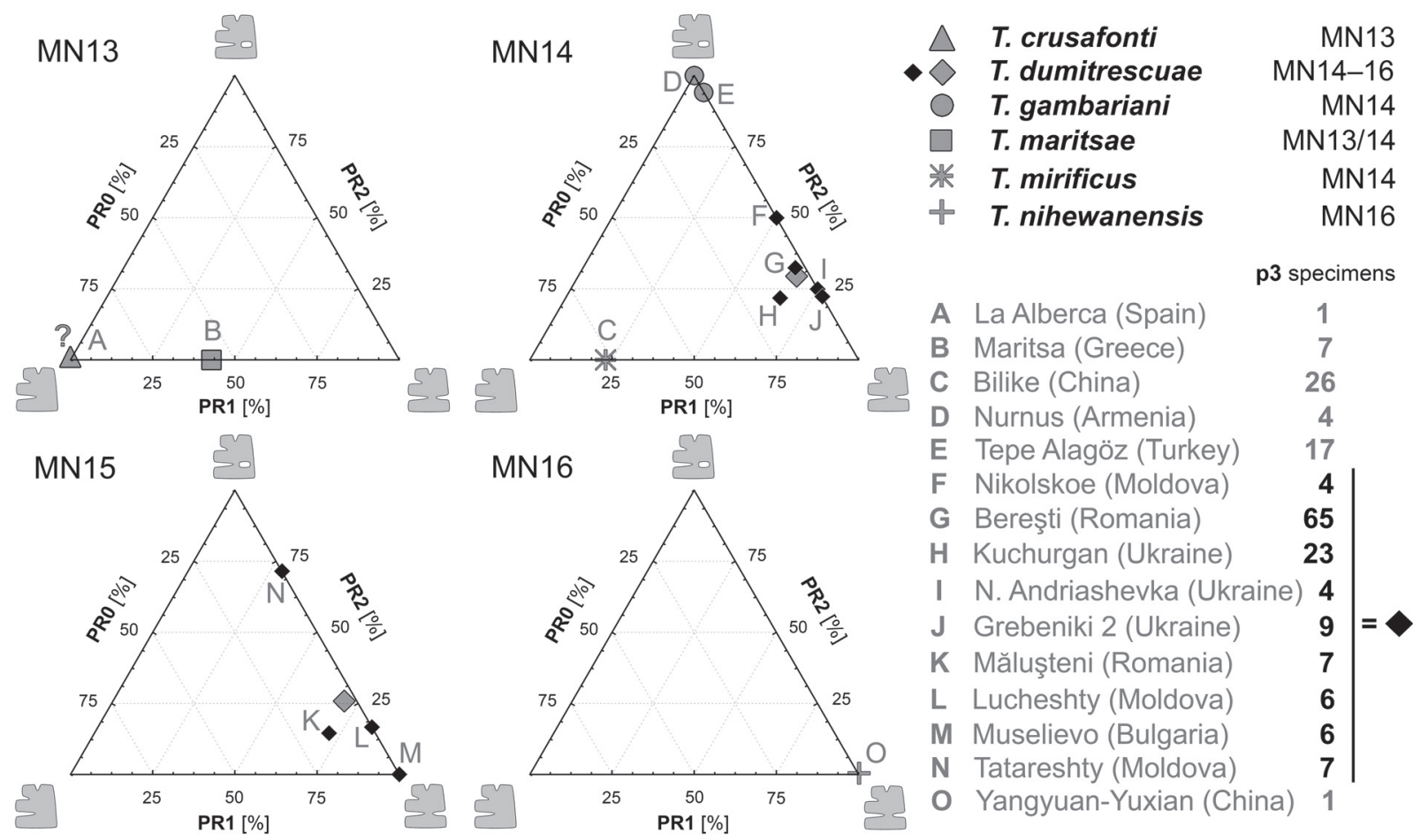

FIGURE 5. Distribution of p3 patterns (PR0-PR2 sensu Čermák et al., 2015) in Eurasian species of Trischizolagus during the late Miocene-early late Pliocene (MN13-16). In T. dumitrescuae, black symbols represent particular localities bearing at least four p3 specimens, grey symbols are mean values for particular MN zones. Data taken from Radulesco and Samson (1967, 1995), de Bruijn et al. (1970), Janvier and Montenat (1971), Topachevsky (1980, 1987), Melik-Adamyan (1986), Cai (1989), Averianov and Tesakov (1997), Qiu and Storch (2000), Popov (2004).

both species share also the 1) variable depth and morphology of p3 anteroconid, 2) well-manifested concavity or even shallow paraflexid in the anterolingual enamel wall of $\mathrm{p} 3$, and 3) hypoconid deformed anterolabially by a depression. The measurements of $\mathrm{p} 3 \mathrm{~s}$ under study fit in the upper range of the dimensional variability of those in type series of $T$. gambariani (Figure 6).

Trischizolagus crusafonti (Janvier and Montenat, 1971) - (La Alberca, Spain; MN 13) and T. maritsae de Bruijn et al., 1970 - (Maritsa, Greece; MN 13/14), both representing the early species of the genus, differ from the taxon under study in its smaller size of p3 (Figure 6) and missing mesofossettid in p3 (i.e., the presence of PR0 and/or PR1 p3 pattern(/s); Figure 5). Nevertheless, it is worth noting that in the case of $T$. maritsae, dimensions of p3 are not easily comparable because the teeth apparently come from subadult individuals (de Bruijn et al., 1970).

Trischizolagus dumitrescuae Radulesco and Samson, 1967, described from the early Pliocene (MN15a) locality of Măluşteni and reported from many Pliocene (MN14-16) localities from southeastern and eastern Europe (Čermák and Wagner,
2013), shows considerable variation in size and morphology of P2/p3. Nevertheless, the species differs from the Tepe Alagöz leporid in its significant predominance of PR1 p3 pattern $(\mathrm{PRO}=$ $3.4 \%, \mathrm{PR} 1=68.4 \%, \mathrm{PR} 2=28.2 ; \mathrm{N}=131$ [9 MN1415 localities]; see Figure 5 for details) and its predominantly simpler P2 (in ca. $70 \%$ of 25 cases; Topachevsky, 1980; Averianov and Tesakov, 1997 and data herein). The p3 and P2 size of taxon under study do not exceed the size range observed in $T$. dumitrescuae (see Čermák and Wagner, 2013); in relation to the type series of $T$. dumitrescue, the available p3s from Tepe Alagöz fit in the lower range of the type series or slightly below (Figure 6). Incisors, both upper and lower, in T. dumitrescuae are anteroposteriorly more elongated that those in T. gambariani (cf. Averianov, 1995); the feature is more expressed in the upper one (L/W is 0.70 for $T$. g. vs 0.84 for $T$. d.; Averianov, 1995, and data herein).

Trischizolagus mirificus described by Qiu and Storch (2000) from the early Pliocene (MN14) locality of Bilike (Inner Mongolia, China) differs from the taxon under study in its considerably simpler ("Hypolagus-like") morphology of p3 (PRO pat- 


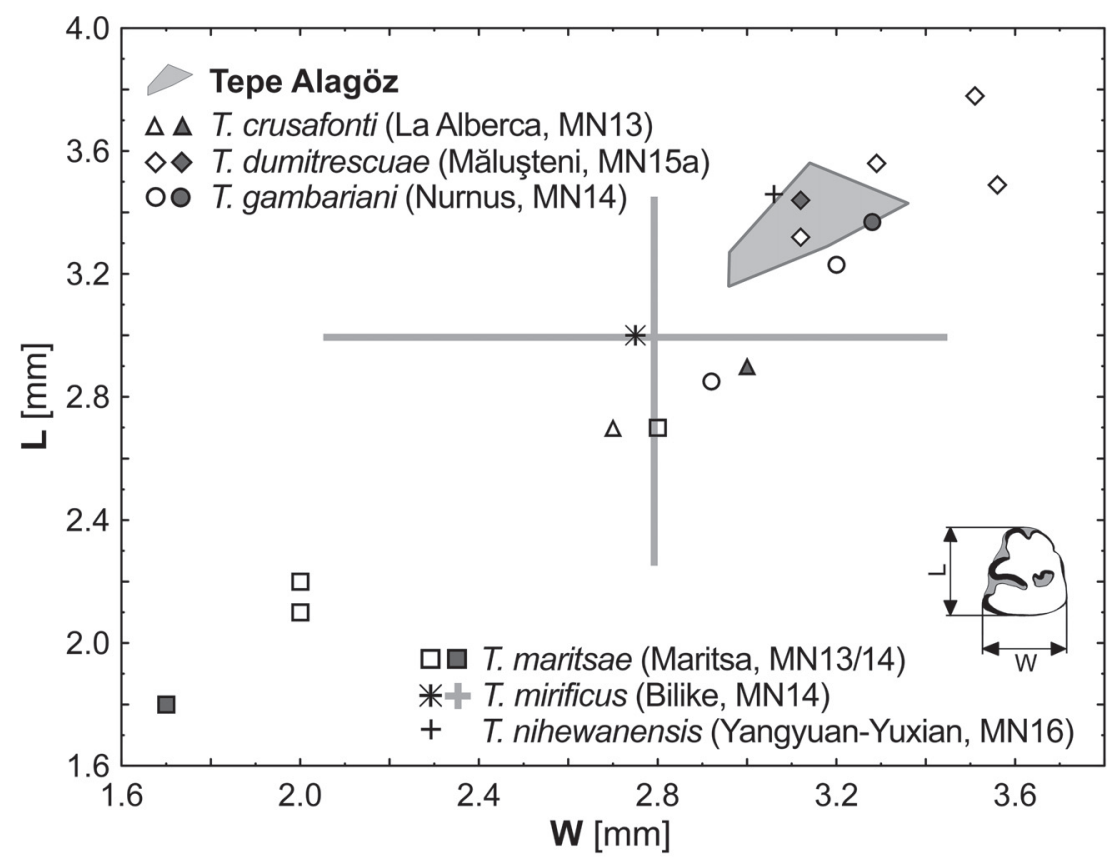

FIGURE 6. The p3 length-to-width scatterplot showing the size relationship among studied Trischizolagus gambariani (Tepe Alagöz, MN14) and type materials of Eurasian late Miocene-Pliocene species of Trischizolagus; closed symbols - name-bearing specimens, open symbols - other specimens of respective type series, in parentheses - type locality and its age. Metric data taken from Radulesco and Samson (1967), de Bruijn et al. (1970), Janvier and Montenat (1971), Melik-Adamyan (1986), Cai (1989), and Qiu and Storch (2000).

tern in $77 \%$ of cases; the pattern with mesofossettid (PR2) absents; $N=25$; Qiu and Storch, 2000). P2 occlusal outline of T. mirificus is also simple, generally of LL-morphotypes I-III and BMR-morphotypes 0-A in contrast to LL-morphotype V/VI and BMR-morphotype B in the material under study. Both taxonomically significant teeth in T. mirificus are smaller than those in the material under study (Figure 6, Table 1, Qiu and Storch, 2000).

Trischizolagus nihewanensis (Cai, 1989), originally referred to Pliopentalagus, was erected based on one p3 and two lower molariform teeth coming from the lower part of the Daodi Formation (late Pliocene) of Yangyuan and Yuixian (Hebei Province, China). The only available p3 differs from the taxon under study in its PR1 p3 pattern and its more infolded enamel walls in posterior structures of teeth. According to Tomida and Jin (2005), the p3 of $T$. nihewanensis is characterized with the most complicated enamel pattern within the genus. The p3 size of $T$. nihewanensis is similar to those in leporid from Tepe Alagöz (Figure 6).

It is worth mentioning here the leporid findings supposedly related to Trischizolagus (in Şen, 1983 and Averianov and Tesakov, 1997; Pliopentalagus sp. and/or Serengetilagus sp. in Şen and Erbajeva, 1995) from the early Pliocene (cf. MN14) locality of Pul-e Charkhi locality, Afghanistan (Şen, 1983). The available two p3s (one fragmentary) do not allow an evaluation of variation. Nevertheless, they differ from the specimens under study in their smaller size $(\mathrm{LxW}=3.05 \times 2.90,-$ x $2.96 \mathrm{~mm}$; measurements of SČ). The fragmentary p3 of Pul-e Charkhi, referred by Şen and Erbajeva (1995, figure 1a) to Pliopentalagus sp., differs also in more infolded posterior walls in talonid structures. In the second p3 of Pul-e Charkhi, possessing the A1/ PR0 pattern, (AFG 759, SČ pers. obs; referred to Trischizolagus cf. maritsae in Şen, 1983; Trischizolagus sp. in Averianov and Tesakov, 1997; Serengetilagus sp. in Şen and Erbajeva, 1995) the mesofossettid is present. Nevertheless, this mesofossettid is located very close to the medial end of the hypoflexid, and is much smaller and rounder than those in Tepe Alagöz leporid (Figure 4).

Other questionable leporid findings compatible with the attribution to Trischizolagus, originally described by Geraads (1994) as Serengetilagus raynali, are known from the Pleistocene locality of Rhino Cave in Morocco. The leporid is similar to the taxon under study in its exclusive appearance 
of the mesofossettid (A1/PR2/Pa1 p3 pattern), but it differs in its very short and wide anteroconid of $p 3$ (in two of four) and significantly smaller $\mathrm{p3}(\mathrm{L} \times \mathrm{W}$ of $\mathrm{p} 3$ : $\mathrm{OR}=2.53-2.90 \times 2.41-2.74, \mathrm{M}=2.62 \times 2.55$ : $\mathrm{N}=4$; Geraads, 1994). Unfortunately, based on the available material the precise generic attribution is still impossible.

Emended diagnosis. Medium-sized leporid possessing: 1) p3 almost exclusively limited to p3 of A1/PR2 pattern with narrow anteroconid and very variable anteroflexid associated with $\mathrm{P} 2$ bearing short paraflexus, relatively long hypoflexus of LLmorphotype between $\mathrm{V}$ and $\mathrm{VI}$, and moderately developed mesoflexus of BMR-morphotype B; 2) anteroposteriorly shortened 11 with shallow Vshaped cement free anterior notch; 3) uncrenulated flexids in lower teeth.

The above combination of features discriminates T. gambariani from: 1) species of Hypolagus bearing A0/PR0 p3; 2) species of Serengetilagus bearing A0-1/PR0 p3; 3) species of Alilepus bearing A0/PR1-2 p3; 4) species of Pliopentalagus bearing crenulated flexids in lower teeth; 5) species of Lepus and Oryctolagus bearing A1/PR3 p3; 6) "Trischizolagus" raynali bearing significantly smaller p3 with shorter and wider anteroconid; and 7) Trischizolagus crusafonti, T. dumitrescuae, $T$. maritsae, T. mirificus, T. nihewanensis bearing, exclusively or predominantly, A1/PR0-1 p3 and P2 (if available) with LL-morphotype 0-IV. Moreover, $T$. crusafonti, T. maritsae, T. mirificus differ in their significantly smaller p3 and $T$. dumiterescuae in its more anteroposteriorly elongated I1.

Stratigraphic and geographic distribution. Early Pliocene (Ruscinian, MN14); southern regions of peri-Paratethyan area, currently Turkey and Armenia [localities Nurnus (AM, MN14, type locality), Tepe Alagöz (TR, MN14)].

\section{DISCUSSION AND CONCLUSIONS}

\section{Tepe Alagöz: Age of the Assemblage}

Biochronologic interpretation of the rodent assemblage from Tepe Alagöz is rather tricky because our rodent material is scarce. Occitanomys debruijni appears together with Pseudomeriones hansi in Anatolia only in the locality of İgdeli (de Bruijn et al., 2013; Suata-Alpaslan, 2009a). On the other hand, Allocricetus cf. bursae from İğdeli slightly differs from our $A$. cf. ehiki. Moreover, the arvicolids are already present in the assemblage from İgdeli while they are absent in the assemblage from Tepe Alagöz. This is, of course, only indirect evidence because their absence may reflect a small sample size. Nevertheless, the Tepe Alagöz rodent assemblage seems to be of about the same age or somewhat older than İğdeli and, thus, represents a time slice close to Miocene/Pliocene transition. In terms of local biozonation, the age of the assemblage from Tepe Alagöz can be interpreted as local zone $M$ that is tentatively correlated to biounit MN14 in Europe (de Bruijn et al., 2013). This is in good accordance with the lagomorph taxa recorded in this locality.

\section{Leporids of Tepe Alagöz: Taxonomy and Paleobiogeography}

The almost exclusive occurrence of anteroflexid together with mesofossettid in the $p 3$ phenotype (i.e., A1/PR2) clearly allows an attribution of leporid material from Tepe Alagöz to the genus Trischizolagus (cf. Radulesco and Samson, 1967; Averianov, 1995; Averianov and Tesakov, 1997; López Martínez et al., 2007; Čermák and Wagner, 2013). Nevertheless, the presence of mesofossettid in $94 \%$ of cases $(N=16)$ is quite unusual among the known Pliocene records of this genus. The fossil record of the earliest species of Trischizolagus represented by $T$. crusafonti (La Alberca, Spain, MN13) and T. maritsae (Maritsa, Greece, MN13/14) is, unfortunately, very scarce and prevents any reliable evaluation of p3 morphotype composition and thus any conclusive comparisons. Available p3s lack a mesofossettid (Figure 5; cf. de Bruijn et al., 1970; Janvier and Montenat, 1971). Note that an atypical weak lingual flexus observed in both available p3s of $T$. crusafonti from the type locality do not allow clear recognition of a mesoflexid (cf. López Martínez et al., 2007). Nevertheless, $\mathrm{p} 3$ of the species is generally attributed to PR0 pattern (e.g., in Averianov and Tesakov 1997; López Martínez et al., 2007; Čermák and Wagner, 2013; this paper, see Figure 5). The mesofossettid has not been documented in either T. mirificus (Bilike, China, MN14) or in T. nihewanensis (Yangyuan-Yuxian, China, MN16). The available p3s of $T$. crusafonti, T. maritsae, and $T$. mirificus generally have a rather simple or primitive appearance, and the phenotype composition in their fossil record suggests the presence of a PRO p3 pattern (Figure 5). The only available p3 of much younger $T$. nihewanensis is of PR1 p3 pattern (Figure 5) with relatively advanced traits with undulation of flexids (Cai, 1989; Tomida and Jin, 2005).

The best known and understood species of the genus is Trischizolagus dumitrescuae documented from almost 20 early Pliocene localities of 
Hungary, Romania, Bulgaria, Greece, Moldova, and southern Ukraine (Radulesco and Samson, 1967, 1995; Topachevsky, 1980, 1987; Averianov and Tesakov, 1997; Popov, 2004; Čermák and Wagner, 2013). No reliable record of the species has been reported from pre-MN14 localities; all of these findings still remain questionable (e.g., Kovalchuk et al., 2017). In the early Ruscinian (MN14) T. dumitrescuae, the PR1 p3 pattern significantly predominates over the PR2 one (66\% vs. $28 \%$ respectively; $N=109$ ), whereas the PR0 p3 pattern is very rare and is present in $6 \%$ of cases (Čermák and Wagner, 2013). During the late Ruscinian (MN15) no significant changes in p3 pattern composition can be observed in the record of $T$. dumitrescuae; the PR1 is available in $68 \%$, PR2 in $29 \%$, and PRO in $3 \%$ of cases $(\mathrm{N}=34$; Čermák and Wagner, 2013, updated). The p3 morphotype compositions of more numerous samples of the species from particular localities are shown in Figure 5. The presumed last appearance most probably belonging to $T$. dumitrescuae (here classified as Trischizolagus sp. - following Averianov and Tesakov, 1997) comes from the early Villányian (early MN16) locality Obukhovka 2 (Russia, Rostov Region).

The available material of Trischizolagus from Nurnus (MN14) originally described by MelikAdamyan (1986) as "Alilepus" gambariani was reassigned as $T$. dumitrescuae by Averianov and Tesakov (1997; contra Čermák and Wagner, 2013). But, although scanty (four p3), its phenotype composition does not fit into the well-documented one of $T$. dumitrescue, where PR1 clearly predominates. Even in other comparably scanty samples of $T$. dumitrescue, the exclusive presence of PR2 specimens has never been documented (Figure 5). It could have been assumed until now that the exclusive presence of the PR2 morphotype could be a result of taphonomic influences (e.g., prey accumulations). But the new material from Tepe Alagöz described here strongly suggests that the uncommon p3 pattern composition recorded in Nurnus is not an accidental phenomenon and that leporids from these coeval localities represents one species, distinct from $T$. dumitrescuae.

The available fossil record of Trischizolagus indicates that the northwestern part of the periParatethyan area can be regarded as the core distribution area of $T$. dumitrescuae. Most known findings of this species reported from there are correlated with the early Ruscinian, and more western occurrences (i.e., from Muselievo (BG) or Beremend $(\mathrm{H})$ ) are limited to the late Ruscinian
(Čermák and Wagner, 2013). South and southeastern parts of the peri-Paratethyan areas, on the other hand, were most probably inhabited by distinct $T$. gambariani, referred from MN14 localities of Nurnus (AM) and Tepe Alagöz (TR). It cannot be excluded that the somewhat younger Trischizolagus reported by Ünay and de Bruijn (1998) from Tozaklar (MN15) also belongs to this species, but the scarcity of material does not allow a definite specific determination. Leporids from Babadat (MN14), Akçaköy (MN14), and Tekman (MN15) referred by Suata-Alpaslan $(2010,2012)$ to Pliopentalagus are reported only in faunal lists without any descriptions or images.

The taxonomy of the geographically close leporid recorded from Maritsa (Rhodos, Greece) has not been fully resolved. The age of the locality is near the Miocene/Pliocene boundary, but there is no consensus on its precise stratigraphic position; it is predominantly correlated with the early MN14 (e.g., de Bruijn et al., 1970; van der Meulen and van Kolfschoten, 1986; Koufos, 2006; Şen et al., 2017), less often with the late MN13 (e.g., Doukas, 2005; Hordijk and de Bruijn, 2009). In our view, it is not possible to give any conclusive argument to support one of the above views for now, thus the age attribution near the MN13/14 boundary is preferred and used here for this locality. Maritsa does appear to be older than Tepe Alagöz and İğdeli. The leporid from Maritsa is commonly regarded as a primitive species within Trischizolagus. With its occlusal p3 outline possessing a less-developed lingual anteroconid and poorly developed lingual structures, the leporid from Maritsa is similar to Trischizolagus crusafonti, hitherto known only from its type locality (La Alberca, S Spain; MN 13). Similar features are also recognizable in the leporid remains from the nearby locality of Alcoy $\mathrm{N}$ (MN13), referred by López Martínez (1989) as $T$. cf. maritsae; the taxon was also reported by the author from the MN13-14 localities Salobreña, Caravaca, and Gorafe 1, but the scarcity of the material from these localities prevents any reliable comparison and taxonomic evaluation. Unsurprisingly, Erbajeva and Angermann (1983) and López Martínez et al. (2007) also point out similarities between the leporid from Maritsa and Serengetilagus praecapensis (the taxon with very low potential to develop lingual structures in p3). This view is also supported by our observations, particularly of leporids from MN13/14 locality of Wádí Natrún ( $N$ Egypt; Studer, 1899; Andrews, 1902) representing the African finding, well-assignable to Serengetilagus (Čermák, unpubl. data), geographically near- 
est to Maritsa. That may indicate an African affinity of the Maritsa leporid. For sake of completeness, it is worth noting in this context that the sporadic single p3 specimens (AFG 759, AMNH 21617) from the early Pliocene localities of Pul-e Charkhi (Afghanistan; Şen, 1983, Şen and Erbajeva, 1995) and Kholobolchi Nor C (Mongolia; Flynn and Bernor, 1987) also possess a similar Serengetilaguslike appearance.

In summary, the leporid from Tepe Alagöz is well co-identifiable with the nominal taxon of $T$. gambariani and not with that of $T$. maritsae, even though the type materials of the both taxa are not fully satisfactory. Based on the available fossil record and present state of our knowledge it is not possible to prove that leporids from Nurnus and Maritsa represent one species. The available data suggest the opposite.

\section{The p3 Mesofossettid in Leporidae: An Unsolved Mystery}

The presence and evolution of mesofossettid during Old World leporid history was reviewed in detail by Čermák et al. (2015). The oldest Old World evidence of a frequent mesofossettid in p3 is documented from the middle-late MN12 of northwestern peri-Paratethysian area in Alilepus laskarewi (Čermák et al., 2015). In this genus the presence of mesofossettid, but significantly less common, can also be observed in $A$. longisinuosus (Lufeng, Yunnan, China; MN12/13; Qi et al., 2006) and sporadically also in $A$. annectens (Ertemte 2, China; MN13; Qiu, 1987). Among other Eurasiatic leporid taxa the mesofossettid shows a high incidence only in Pliopentalagus species; within the latest Miocene - late Pliocene lineage $P$. huainanensis Jin, 2004 - P. dajushanensis Tomida and Jin, 2009 - P. anhuiensis Tomida and Jin, 2009 the p3 mesofossettid is gradually reduced in relation to the mesoflexid (in more detail in Tomida and Jin, 2009; Čermák et al., 2015). The only European record of this genus is the early Pliocene (MN15) $P$. dietrichi (Fejfar, 1961), which p3 shows an exclusively PR1 morphotype.

In addition, there are a number of Old World leporid fossils of unsure species/genus attribution, where p3 mesofossettids are also seen. The small enamel lake (?mesofossettid) located close to the medial end of hypoflexid is observable in the poorly preserved p3 (AFG 759; SČ, pers. obs.) from the early Pliocene (MN14) Pul-e Charkhi locality, Afghanistan (referred to Trischizolagus cf. maritsae in Şen, 1983; Trischizolagus sp. in Averianov and Tesakov, 1997; Serengetilagus sp. in Şen and
Erbajeva, 1995). In the latest Pliocene and early Pleistocene of China there is a group of leporids in which the stable p3 mesofossettid (/enamel lake), of different morphology and location, is associated with the simple p3 anteroconid (A0/PR2 p3 morphotype). This p3 morphotype has generally been found together with teeth of A0/PR0 or A0/PR1 morphotype. Taxonomy of these leporids is still poorly understood, and their generic attribution still remains unclear. These have generally been identified with the species brachypus described by Young (1927) and originally assigned in the genus Caprolagus. The type material was referred by various authors to different genera: to Hypolagus by Schreuder (1937), to Alilepus by Gureev (1964) followed by Cai (1989), to Sericolagus by Averianov (1996; erected as new) - followed by Wu and Flynn (2017), to Brevilagus by Zhang, Z.-Q. (2001; the junior objective synonym of Sericolagus). Over the past several decades, findings considered to be related to this species (reported under various generic assignment) have been reported from China including - Loc. 2 of Gaojiaya, Jingle (Teihard de Chardin and Young,1931); Loc. 22 of Shouyang (Young, 1935); Loc. 18 (Teilhard de Chardin, 1940); Yushe (Teilhard de Chardin, 1940; Wu and Flynn, 2017); Heshui of Gansu (Zheng, 1976); Jinniushan of Liaoning (Zhang, S.-S., 1993); the East and West Caves near Zhoukoudian (Cheng et al., 1996); Sunjiashan of Zibo (Zheng et al., 1997); Ningyang (Zhang, Z.-Q., 2001); Fanchang, Anhui (Jin and Xu, 2009).

It is worth mentioning in this context the questionable leporid findings from the Pleistocene locality Rhino Cave in Morocco originally described by Geraads (1994) as Serengetilagus raynali. The exclusive presence of the mesofossettid and predominantly very wide anteroconid in p3 strongly support the view by Şen and Erbajeva (1995), Averianov and Tesakov (1997), and López Martínez et al. (2007), which put the Moroccan leporid apart from the African taxa referred to Serengetilagus. Averianov and Tesakov (1997) referred these specimens as Trischizolagus sp., but the presence of a markedly square outline of p3 with very short and wide anteroconid and distinctly young age of these findings do not fully support an attribution to this genus. The features are rather typical for Oryctolagus.

A predisposition to development of this structure has been available already in the earliest forms of Leporinae (Čermák et al., 2015); the initial appearance is recorded from the middle Miocene (late Barstovian) of North America (Voorhies and 
Timperley, 1997). Based on the leporid record discussed above, together with well-documented one of North America (Dawson, 1958; White 1988, 1991), we can conclude that the presence of mesofossettid (/enamel lake) in leporid p3 is a relatively common phenomenon. It is well associated with both $\mathrm{A} 0$ and $\mathrm{A} 1 \mathrm{p} 3$ anteroconid type (i.e., with anteroflexid or without it) in various ratios and morphologies across genera. Taxonomically significant differences related to this structure can often be found on the species level.

Hypolagus, a widespread and well understood genus of Archaeolaginae, rarely has similar tooth structures (Fladerer and Reiner, 1996). If present, the enamel lake is generally small and simple, located close to the medial end of hypoflexid, and often is not present along the entire tooth shaft. Most likely the lake was derived from the medial end of hypoflexid or even accidentally, independently to any adjoining structures (Čermák et al., 2015). This could be the case of leporid p3 from Pul-e Charkhi (Şen, 1983; Şen and Erbajeva, 1995) and also Sericolagus yushecus (Wu and Flynn, 2017: figure 4.10b). In Leporinae, a predisposition to development of posterolingual tooth structures together with anteroflexids is significantly higher. These structures appear across the Leporinae lineage in various combinations and ratios and often are taxonomically discriminative for numerous species and genera (Hibbard, 1963; White, 1991; Čermák et al., 2015).
So, the available fossil record in many leporid lineages suggests different origins of enamel lake in p3 (Čermák et al., 2015). Moreover, even within Leporinae clade the p3 PR1/PR2 changes over time in different lineages show different morphoclines, compare e.g. lineage Alilepus $=>$ Nekrolagus $=>$ Lepus/Sylvilagus (Hibbrad, 1963; Averianov and Tesakov, 1997) vs above mentioned east Asiatic lineage of Pliopentalagus species (Tomida and Jin, 2009). Thus a generally accepted Hibbard (1963) hypothesis proposing the development of posterointernal structures of $\mathrm{p} 3$ in the sequence mesoflexid $=>$ mesofossettid has a limited validity (Čermák et al., 2015). In this perspective, it is also not surprising that development of the anteroflexid is a phenomenon that appeared independently several times in different lineages (White, 1991).

\section{ACKNOWLEDGMENTS}

We would like to thank to M. Kováčová, I. Mazzini, and M. Poliak for their help during the field campaign. We thank also four anonymous reviewers for valuable comments and critical remarks. Sč has been supported by institutional support RVO67985831 of the Institute of Geology of the Czech Academy of Sciences. PJ has been supported by VEGA 1/0702/17 and Slovak Research and Development Agency (SRDA) Grant APVV-150575 .

\section{REFERENCES}

Agadjanian, A.K. and Erbajeva, M.A. 1983. Late Cenozoic Rodents and Lagomorphs of the USSR. Nauka, Moscow. (In Russian)

Andrews, C.W. 1902. Note on a Pliocene vertebrate fauna from the Wadi-Natrun, Egypt. Geological Magazine, 9:433-439. https://doi.org/10.1017/S0016756800178112

Argyropulo, A.I. and Pidoplichka, I.G. 1939. Representatives of Ochotonidae (Duplicidentata, Mammalia) in the Pliocene of the USSR. Doklady Akademii Nauk SSSR, 24(7):723-728. (In Russian)

Averianov, A. 1995. Osteology and adaptations of the Early Pliocene rabbit Trischizolagus dumitrescuae (Lagomorpha: Leporidae). Journal of Vertebrate Paleontology, 15:375-386. https://doi.org/10.1080/02724634.1995.10011236

Averianov, A.O. 1996. On the systematic position of rabbit "Caprolagus" brachypus Young, 1927 (Lagomorpha, Leporidae) from the Villafranchian of China. Russian Academy of Sciences, Proceedings of the Zoological Institut, 270,148-156. (In Russian with English summary)

Averianov, A. and Tesakov, A.S. 1997. Evolutionary trends in Mio-Pliocene Leporinae, based on Trischizolagus (Mammalia, Lagomorpha). Paläontologische Zeitschrift, 71:145-153. https:// doi.org/10.1007/bf03022556

Bowdich, T.E. 1821. An Analysis of the Natural Classifications of Mammalia, for the Use of Students and Travelers. J. Smith, Paris. 
Brandt, J.F. 1855. Beiträge zur näheren Kenntniss der Säugethiere Russlands. Mémoire de l'Académie impériale des Sciences, St. Petersburg, Physique, Mathématique, et Naturalistique, 6(9):1-365.

Cai, B. 1989. Fossil Lagomorpha from the Late Pliocene of Yangyuan and Yuxian counties, Hebei Province. Vertebrata PalAsiatica, 27:170-181. (In Chinese with English abstract)

Čermák, S. 2007. New finds of Ochotonoma csarnotana (Lagomorpha, Ochotonidae) from the Pliocene of Hungary: a new look on the species. Neues Jahrbuch für Geologie und Palaontologie - Abhandlungen, 246:247-256. https://doi.org/10.1127/0077-7749/2007/02460247

Čermák, S. 2009. The Plio-Pleistocene record of Hypolagus (Lagomorpha, Leporidae) from the Czech and Slovak Republics with comments on systematics and classification of the genus. Bulletin of Geosciences, 84:497-524. https://doi.org/10.3140/bull.geosci.1104

Čermák, S. 2010. The Late Miocene and Pliocene Ochotoninae (Lagomorpha, Mammalia) of Europe - the present state of knowledge, p. 9-28. In Nowakowski, D. (ed.), Morphology and Systematics of Fossil Vertebrates. DN Publisher, Wrocław.

Čermák, S. 2016. The Late Miocene species Ochotona kalfense (Mammalia, Lagomorpha) of Moldova: The oldest European record of the genus in the context of the earliest Ochotoninae. Comptes Rendus Palevol, 15:927-940. https://doi.org/10.1016/j.crpv.2016.04.010

Čermák, S., Angelone, C., and Sinitsa, M.V. 2015, New Late Miocene Alilepus (Lagomorpha, Mammalia) from Eastern Europe casts a new light on the evolution of the earliest Old World Leporinae. Bulletin of Geosciences, 90:431-451. https://doi.org/10.3140/bull.geosci.1523

Čermák, S. and Rekovets, L.I. 2010. Early Pliocene ochotonids (Mammalia, Lagomorpha) of Southern Ukraine. Geodiversitas, 32:107-120. https://doi.org/10.5252/g2010n1a3

Čermák, S. and Wagner, J. 2013. The Pliocene record of Trischizolagus and Pliopentalagus (Leporidae, Lagomorpha, Mammalia) in Central Europe with comments on taxonomy and evolutionary history of Leporinae. Neues Jahrbuch fur Geologie und Paläontologie Abhandlungen, 268:97-111. https://doi.org/10.1127/0077-7749/2013/0321

Cheng, J., Tian, M.-Z., Cao, B.-X., and Li, L.-Y. 1996. The New Mammalian Fossils from Zhoukoudian (Choukoutien), Beijing, and their Environmental Explanation. China University of Geosciences Press, Beijing. (In Chinese with English abstract)

Çiner, A., Aydar, E., Dirik, K., Rojay, B., Ersoy, O., Özsayin, E., Sayin, E., Çubukcu, H.E., and Yıldırım, C. 2012. Continental plateaus and tectonics-climate interactions. ESF-TUBITAK $107 Y 300$ - Vertical Anatolian Movements Project (VAMP). TUBITAK Project Report (20082012), Ankara.

Cuenca-Bescós, G., 2003. Análisis filogenético de Allocricetus del Pleistoceno (Cricetidae, Rodentia, Mammalia). Coloquios Paleontología. Vol. extra 1:95-103.

Daams, R. and Freudenthal, M. 1988. Cricetidae (Rodentia) from the type-Aragonian; the genus Megacricetodon. Scripta Geologica, 1:39-132.

Dawson, M. 1958. Late Tertiary Leporidae of North America. University of Kansas Paleontological Contributions, 6:1-75.

de Bruijn, H., Dawson, M.R., and Mein P. 1970. Upper Pliocene Rodentia, Lagomorpha and Insectivora (Mammalia) from the Isle of Rhodes (Greece) I. II. III. Proceedings of the Koninklijke Nederlandse Akademie Van Wetenschappen, Series B, 73(5):535-584.

de Bruijn, H., Ünay, E., and Hordijk, K. 2013. A review of the Neogene succession of the Muridae and Dipodidae from Anatolia, with special reference to taxa known from Asia and/or Europe, p.566-582. In Wang, X., Flynn, L.J., and Fortelius, M. (eds.), Fossil Mammals of Asia. Neogene Biostratigraphy and Chronology. Columbia University Press, New York. https:// doi.org/10.7312/columbia/9780231150125.003.0026

Dice, L.R. 1917. Systematic position of several Tertiary lagomorphs. University of California Publications, Bulletin of the Department of Geology, 10:179-183.

Dice, L.R. 1931. Alilepus, a new name to replace Allolagus Dice, preoccupied, and notes on several species of fossil hares. Journal of Mammalogy, 12:159-160. https://doi.org/10.2307/ 1373916

Dietrich, W.O. 1941. Die säugetierpaläontologischen Ergebnisse der Kohl-Larsen'schen Expedition 1937-1939 in nördlichen Deutsch-Ostafrika. Zentralblatt für Mineralogie, Geologie und Paläontologie, Abt. B, 1941(8): 217-223.

Doukas, C.S. 2005. Greece, p. 99-112. In Hoek Ostende van den, L.W., Doukas, C.S., and Reumer, J.W.F. (eds.), The fossil record of the Eurasian Neogene insectivores (Erinaceomorpha, Soricomorpha, Mammalia), part I. Scripta Geologica, Special Issue 5. 
Erbajeva, M.A. 1988. Cenozoic Pikas (Taxonomy, Systematics, Phylogeny). Nauka, Moscow. (In Russian)

Erbajeva, M.A. and Angermann, R. 1983. Das Originalmaterial von Serengetilagus praecapensis Dietrich, 1941 - ergänzende Beschreibung und vergleichende Diskussion. Schriftenreihe für geologische Wissenschaften, 19/20:39-60.

Erbajeva, M.A. and Shushpanov K.I. 1988. The Pliocene pikas of Moldavia. Vestnik Zoologii, 4:55-60. (In Russian)

Fejfar, O., 1961. Die plio-pleistozänen Wirbeltierfaunen von Hajnáčka und Ivanovce (Slowakei), ČSSR. III. Lagomorpha. Neues Jahrbuch für Geologie und Paläontologie, Monatshefte, 5:267-282.

Fischer, G. 1817. Adversaria zoologica. Memoires de la Société Impériale des Naturalistes du Moscou, 5:357-428.

Fladerer, F.A. 1987. Beitrag zur Entwicklung von Hypolagus und Lepus (Lagomorpha, Mammalia) im Pliopleistozän von Mitteleuropa. Sitzungsberichte der Österreichische Akademie der Wissenschaften, Mathematisch-naturwissenschaftliche Klasse, Abteilung I, 196:123-138.

Fladerer, F.A. and Reiner, G. 1996. Evolutionary shifts in the first premolar pattern of Hypolagus beremendensis (Petényi, 1964) (Lagomorpha, Mammalia) in the Plio-Pleistocene of Central Europe. Acta Zoologica Cracoviensia, 39:147-160.

Flynn, I.J. and Bernor, R.L. 1987. Late Tertiary mammals from the Mongolian People's Republic. American Museum Novitates, 2872:1-16.

Geraads, D. 1994. Rongeurs et Lagomorphes du Pléistocène moyen de la "Grotte des Rhinocéros", carrière Oulad Hamida 1, à Casablanca, Maroc. Neues Jahrbuch für Geologie und Paläontologie, Abhandlungen, 191:147-172.

Görür, N., Tüysüz, O., and Şengör, A.M.C. 1998. Tectonic evolution of the central Anatolian basins. International Geology Review, 40:831-850. https://doi.org/10.1080/ 00206819809465241

Gray, J.E. 1825. Outline of an attempt at the disposition of the Mammalia into tribes and families with a list of the genera apparently appertaining to each tribe. Annals of Philosophy, 10(New Series 2):337-344.

Gureev, A.A. 1964. Fauna of the USSR (Lagomorpha), Vol. 3 (10). Nauka, Moscow, Leningrad. (In Russian)

Hibbard, C.W. 1963. The origin of the p3 pattern of Sylvilagus, Caprolagus, Oryctolagus and Lepus. Journal of Mammalogy, 44:1-15. https://doi.org/10.2307/1377162

Hordijk, K. and de Bruijn, H., 2009. The succession of rodent faunas from the Mio/Pliocene lacustrine deposits of the Florina-Ptolemais-Servia Basin (Greece). Hellenic Journal of Geosciences. 44:21-103.

ICZN, 1999. International Code of Zoological Nomenclature, 4th Edition. International Trust for Zoological Nomenclature, London. https://doi.org/10.5962/bhl.title.50608

Illiger, C. 1811. Prodromis Systematis Mammalium et Avium Additis Terminis Zoographicis Utriusque Classis. C. Salfeld, Berlin. https://doi.org/10.5962/bhl.title.106965

Janvier, P. and Montenat, C. 1971. Le plus ancien léporidé d'Europe occidentale, Hispanolagus crusafonti, nov. gen., nov. sp., du Miocène supérieur de Murcia (Espagne). Bulletin du Muséum National d'Histoire naturelle Paris, 42:780-788.

Jin, C.-Z. 2004. Fossil leporids (Mammalia, Lagomorpha) from Huainan, Anhui, China. Vertebrata PalAsiatica, 42:230-245. (In Chinese with English summary)

Jin, C.-Z. and Xu, F. 2009. Lagomorpha, p. 162-166, 400-401. In Jin, C.-Z. and Liu, J.-Y. (eds.), Paleolithic Site-The Renzidong Cave, Fanchang, Anhui Province. Science Press, Beijing.

Kaymakçı, N. 2000. Tectono-stratigraphical evolution of the Çankırı basin (central Anatolia, Turkey). Geologica Ultraiectina, 190:1-247.

Khomenko, J. 1914. La faune méotique du village Taraklia du district de Bendery. Travaux de la Société des Naturalistes et des Amateurs des Sciences Naturelles de Bessarabie, 5:1-55.

Koufos, G.D. 2006. The Neogene mammal localities of Greece: Faunas, chronology and biostratigraphy. Hellenic Journal of Geosciences, 41:183-214.

Kovalchuk, O.M., Gorobets, L.V., Syromyatnikova, E.V., Danilov, I.G., Titov, V.V., Krakhmalnaya, T.V., Rekovets, L.I., and Zelenkov, N.V. 2017. Vertebrates from the Pontian of the Shkodova Gora Locality (Northwestern Black Sea Region, Upper Miocene). Paleontological Journal, 51:414-429. https://doi.org/10.1134/s0031030117040050 
Lilljeborg, W. 1874. Sveriges och Norges Ryggradsdjur. 1. Däggdjuren, jemte inledning till ryggradsdjuren. Förra afdelningen. W. Schultz, Upsala. https://doi.org/10.5962/bhl.title.82672

Linnaeus, C. 1758. Systema Naturae per Regna Tria Naturae, Secundum Classis, Ordines, Genera, Species cum Characteribus, Differentiis, Synonymis, Locis, Editio Decima, Reformata. Vol. I. Laurentii Salvii, Stockholm. https://doi.org/10.5962/bhl.title.542

López Martínez, N. 1989. Revisión sistemática y biostratigráfica de los Lagomorpha (Mammalia) del Terciario y Cuaternario de España. Memorias del Museo Paleontológico de la Universidad de Zaragoza, 3:1-342.

López Martínez, N., Likius, A., Mackaye, H.T., Vignaud, P., and Brunet, M. 2007. A new lagomorph from the Late Miocene of Chad (Central Africa). Revista Espańola de Paleontología, 22:1-20.

Lungu A.N. 1981. Hipparion Fauna of Middle Sarmatian of Moldavia (Insectivora, Lagomorpha and Rodentia). Shtiintsa Press, Kishinev. (In Russian)

Lüttig, G. and Steffens, P. 1976. Explanatory Notes for the Paleogeographic Atlas of Turkey from Oligocene to the Pleistocene. Bundesanstalt für Geowissenschaften und Rohstoffe, Hannover.

Mazzini, I., Hudackova, N., Joniak, P., Kovacova, M., Mikes, T., Mulch, A., Rojay, B., Lucifora, S., Esu, D., and Soulie-Marsche, I. 2013. Palaeoenvironmental and chronological constraints on the Tuğlu Formation (Çankırı Basin, Central Anatolia, Turkey). Turkish Journal of Earth Science, 22:747-777.

Melik-Adamyan, G.U. 1986. New data on the Pliocene terrestrial vertebrates of Armenian SSR. Doklady Akademii Nauk Armyanskoy SSR, 83(3):135-139. (In Russian)

Michaux, J. 1969. Muridae (Rodentia) du Pliocène supérieur d'Espagne et du midi de la France. Palaeovertebrata, 3:1-25. https://doi.org/10.18563/pv.3.1.1-25

Palacios, F. and López Martínez, N. 1980. Morfología dentaria de las liebres europeas (Lagomorpha, Leporinae). Doñana Acta Vertebrata, 7:61-81.

Popov, V.V. 2004. Pliocene small mammals (Mammalia, Lipotyphla, Chiroptera, Lagomorpha, Rodentia) from Muselievo (North Bulgaria). Geodiversitas, 26:403-491.

Qi, G.-Q., Dong, W., Zheng, L., Zhao, L., Gao, F., Yue, L.-P., and Zhang, Y.-X. 2006. Taxonomy, age and environment status of the Yuanmou hominoids. Chinese Science Bulletin 51:704712. https://doi.org/10.1007/s11434-006-0704-5

Qiu, Z.-D. 1987. The Neogene mammalian faunas of Ertemte and Harr Obo in Inner Mongolia (Nei Mongol), China. 6. Hares and pikas - Lagomorpha: Leporidae and Ochotonidae. Senckenbergiana Lethaea, 67:375-399.

Qiu, Z.-D. and Storch, G. 2000. The early Pliocene micromammalian fauna of Bilike, Inner Mongolia, China (Mammalia: Lipotyphla, Chiroptera, Rodentia, Lagomorpha). Senckenbergiana Lethaea, 80:173-229. https://doi.org/10.1007/bf03043669

Radulesco, C. and Samson, P. 1967. Contribution à la connaissance du complexe faunistique de Malusteni-Beresti (Pléistocène inférieur), Roumanie I. Ord. Lagomorpha, Fam. Leporidae. Neues Jahrbuch für Geologie und Paläontologie, Monatshefte, 1967(9):544-563.

Radulesco, C. and Samson, P.-M. 1995. The mammals of the Dacian. p. 506-528. In Marinescu, F. and Papaianopol, I. (eds.), Dacien Chronostratigraphie und Neostratotypen Neogen der Zentrale Paratethys. Editure Academiei Române, Bucureşti.

Rojay, B., Altiner, D., Özkan Altiner, S., Önen, P., James, S., and Thirlwall, M.F. 2004. Geodynamic significance of the Cretaceous pillow basalts from North Anatolian Ophiolitic Mélange Belt (Central Anatolia, Turkey): geochemical and paleontological constraints. Geodinamica Acta, 17:349-361. https://doi.org/10.3166/ga.17.349-361

Schaub, S. 1930. Quartäre und jungtertiäre Hamster. Abhandlungen des Schweizerischen Paläontologische Gesellschaft, 49(6):1-49

Schaub, S. 1934. Über einige fossile Simplicidentaten aus China und der Mongolei. Abhandlungen der Schweizerischen Palaeontologischen Gesellschaft, 54(2):1-40.

Schreuder, A. 1937. Hypolagus from the Tegelen clay; with a note on recent Nesolagus. Archives Néerlandaises de Zoologie, 2:225-239. https://doi.org/10.1163/187530137x00087

Şen, Ş. 1983. Rongeurs et lagomorphes du gisement Pliocène de Pul-e Charkhi, bassin de Kabul, Afghanistan. Bulletin du Muséum National d'Histoire Naturelle, 5:33-74.

Şen, Ş. 1998. Pliocene vertebrate locality of Çalta, Ankara, Turkey. 4. Rodentia and Lagomorpha. Geodiversitas, 20:359-378. 
Şen, Ş. 2003. Lagomorpha, p. 163-178. In Fortelius, M., Kappelman, J., Şen Ş., and Bernor, R.L. (eds.), Geology and Paleontology of the Miocene Sinap Formation, Turkey. Columbia University Press, New York.

Şen, Ş., Bouvrain, G., and Geraads, D. 1998. Pliocene vertebrate locality of Çalta, Ankara, Turkey. 12. Paleoecology, biogeography and biochronology. Geodiversitas, 20:497-510.

Şen, Ş., Delfino, M., and Kazanci, N. 2017. Çeştepe, a new early Pliocene vertebrate locality in Central Anatolia and its stratigraphic context. Annales de Paléontologie, 103:149-163. https:/ /doi.org/10.1016/j.annpal.2017.01.004

Şen, Ş. and Erbajeva, M. 1995. Early Pliocene leporids (Mammalia, Lagomorpha) from Afghanistan. Comptes Rendus de l'Académie des Sciences de Paris, Série II, 320:12251231.

Sen, S., Karadenizli, L., Antoine, P., and Saraç, G. (2019). Late Miocene-early Pliocene rodents and lagomorphs (Mammalia) from the southern part of Çankırı Basin, Turkey. Journal of Paleontology, 93(1):173-195. https://doi.org/10.1017/jpa.2018.60

Şen, Ş., Jaeger, J.J., Dalfes, N., Mazin, J.M., and Bocherens, H., 1989. Discovery of a Pliocene small mammal fauna in Western Anatolia. Comptes Rendus de l'Académie des Sciences de Paris, Série II, 309:1729-1734.

Şengör, A.M.C. and Yılmaz, Y. 1981. Tethyan evolution of Turkey: a plate tectonic approach. Tectonophysics, 75:181-241. https://doi.org/10.1016/0040-1951(81)90275-4

Studer, T. 1899. Ueber fossile Knochen von Wadi-Natrùn, Unteregypten. Mittheilungen der Naturforschenden Gesellschaft in Bern, 1451-1462:72-77.

Suata-Alpaslan, F. 2009a. Pseudomeriones hansi nov. sp. (Rodentia, Mammalia) from the Early Pliocene (Ruscinian) fauna of Iğdeli (Turkey). The Open Geology Journal, 3:58-63. https:// doi.org/10.2174/1874262900903010058

Suata-Alpaslan, F. 2009b. Occitanomys (Rhodomys) vandami nov. sp. (Muridae, Mammalia) from the Early Pliocene/Early Ruscinian fauna of Iğdeli (Turkey). The Open Geology Journal, 3:64-69. https://doi.org/10.2174/1874262900903010064

Suata-Alpaslan, F. 2009c. Ochotona mediterranensis nov. sp. (Lagomorpha-Mammalia) from Early Pliocene of Iğdeli (Anatolia-Turkey). SGEM2009 Conference Proceedings of the 9th International Multidisciplinary Scientific GeoConference, 1:99-103.

Suata-Alpaslan, F. 2010. The paleoecology of the continental Early Pliocene of the eastern Mediterranean, a construction based on rodents. Fen Bilimleri Dergisi, 31(2):29-48. (In Turkish)

Suata-Alpaslan F. 2012. Anadolu Erken Pliyosen küçük memeli topluluğu: Paleontolojik ve paleoekolojik anlamları. Kültür Varlıkları ve Müzeler Genel Müdürlüğü, 154:1-13.

Teilhard de Chardin, P. 1940. The fossils from Locality 18 near Peking. Palaeontologia Sinica, New Series, C, 9:1-100.

Teilhard de Chardin, P. and Young, C.C. 1931. Fossil mammals from the late Cenozoic of Northern China. Palaeontologia Sinica, C, 9:1-89.

Terzea, E. 1997. Biochronologie du Pliocène du bord méridional du bassin Dacique (Roumanie), p. 649-660. In Aguilar, J.-P., Legendre, S., and Michaux, J. (eds.), Actes du Congrès BiochroM'97. Mémoires et Travaux de l'EPHE, Institut de Montpellier.

Thomas, O. 1897. On the genera of rodents: an attempt to bring up to date the current arrangement of the order. Proceedings of the Zoological Society of London, 1896:11121128.

Tomida, Y. and Jin, C.-Z. 2005. Reconsideration of the generic assignment of "Pliopentalagus nihewanensis" from the late Pliocene of Hebei, China. Vertebrata PalAsiatica, 43:297-303.

Tomida, Y. and Jin, C.-Z., 2009. Two new species of Pliopentalagus (Leporidae, Lagomorpha) from the Pliocene of Anhui Province, China, with a revision of Pl. huainanensis. Vertebrata PalAsiatica, 47:53-71.

Tong, H. 1989. Origin and evolution of the Gerbillidae (Mammalia, Rodentia) in North Africa. Mémoires de la Société géologique de France. 155:1-120.

Topachevsky, I.V. 1980. New species of genus Pratilepus (Lagomorpha, Leporidae) from Pliocene deposits of Kuchurgan sediments. Vestnik Zoologii, 5:37-40. (In Russian)

Topachevsky, I.V. 1987. First finding of a representative of Serengetilagus (Lagomorpha, Leporidae) from the Pliocene deposits of Eastern Europe. Vestnik Zoologii, 6:48-51. (In Russian)

Ünay, E. and de Bruijn, H. 1998. Plio-Pleistocene rodents and lagomorphs from Anatolia, Central Turkey, p. 431-466. In van Kolfschoten, T. and Gibbard, P.L. (eds.), The Dawn of the 
Quaternary. (Proceedings of the SEQS-EuroMam Symposium 1996). Mededelingen Nederlands Instituut voor Toegepaste Wetenschappen TNO.

Ünay, E., de Bruijn, H., and Saraç, G. 2003. A preliminary zonation of the continental Neogene of Anatolia based on rodents, p. 539-547. In Reumer, J.W.F. and Wessels, W. (eds.), Distribution and Migration of Tertiary Mammals in Eurasia. A Volume in Honour of Hans de Bruijn. Deinsea 10.

van den Hoek Ostende, L.W., Gardner, J.D., van Bennekom, L., Alçiçek, M.C., Murray, A.M., Wesselingh, F.P., Alçiçek, H., and Tesakov, A.S. 2015. Ericek, a new Pliocene vertebrate locality from the Çameli Basin (SW Anatolia, Turkey). Palaeobiodiversity and Palaeoenvironments, 95: 305-320. https://doi.org/10.1007/s12549-015-0202-3

van der Meulen, A. and van Kolfschoten, T. 1986. Review of the Late Turolian to Early Biharian mammal faunas from Greece and Turkey. Memoria Società Geologia Italiana. 31:201-211.

van de Weerd, A. 1976. Rodent faunas of the Mio-Pliocene continental sediments of the TeruelAlfambra region, Spain. Utrecht Micropaleontogical Bulletins, 2:218-218.

Voorhies, M.R. and Timperley, C.L. 1997. A new Pronotolagus (Lagomorpha: Leporidae) and other leporids from the Valentine Railway Quarries (Barstovian, Nebraska), and the archaeolagine-leporine transition. Journal of Vertebrate Paleontology, 17:725-737. https:// doi.org/10.1080/02724634.1997.10011020

White, J.A. 1988. The Archaeolaginae (Mammalia, Lagomorpha) of North America, excluding Archaeolagus and Panolax. Journal of Vertebrate Paleontology, 7:425-450. https://doi.org/ 10.1080/02724634.1988.10011674

White, J.A. 1991. North American Leporinae (Mammalia: Lagomorpha) from late Miocene (Clarendonian) to latest Pliocene (Blancan). Journal of Vertebrate Paleontology, 11:67-89. https://doi.org/10.1080/02724634.1991.10011376

Wu, W.-Y. and Flynn, L.J. 2017. The Lagomorphs (Ochotonidae, Leporidae) of Yushe Basin, p. 31-57. In Flynn, L.J. and Wu, W.-Y. (eds.), Late Cenozoic Yushe Basin, Shanxi Province, China: Geology and Fossil Mammals, Volume II: Small Mammal Fossils of Yushe Basin, Vertebrate Paleobiology and Paleoanthropology. Springer, Dordrecht. https://doi.org/ 10.1007/978-94-024-1050-1_4

Young, C.C. 1927. Fossile Nagetiere aus Nord-China. Palaeontologia Sinica, C, 5(3):1-82.

Young, C.C. 1935. Miscellaneous mammalian fossils from Shansi and Honan. Palaeontologia Sinica, C, 9(2):1-56.

Zhang, S.-S. 1993. Comprehensive study on the Jinniushan Paleolithic site. Memoirs of Institute of Vertebrate Palaeontology and Palaeoanthropology. Academia Sinica, 19.1-153.

Zhang, Z.-Q. (2001). Fossil mammals of early Pleistocene from Ningyang, Shandong Province. Vertebrata PalAsiatica, 39:139-150.

Zheng, S.-H. 1976. Small mammals of middle Pleistocene in Heshui, Gansu. Vertebrata PalAsiatica, 14:112-119. (In Chinese)

Zheng, S.-H., Zhang, Z.-Q., and Liu, L.-P. 1997. Pleistocene mammals from fissure-filling of Sunjiashan hill, Shandong, China. Vertebrata PalAsiatica, 35:215-221. (In Chinese with English summary) 